GLOBAL WATER PATHOGEN PROJECT

PART FOUR. MANAGEMENT OF RISK FROM EXCRETA AND WASTEWATER

\title{
SLUDGE MANAGEMENT: BIOSOLIDS AND FECAL SLUDGE
}

\author{
James Mihelcic \\ University of South Florida \\ Tampa, United States
}




\section{Copyright:}

\section{cc) (1) (2) \\ BY SA}

This publication is available in Open Access under the Attribution-ShareAlike 3.0 IGO (CC-BY-SA 3.0 IGO) license (http://creativecommons.org/licenses/by-sa/3.0/igo). By using the content of this publication, the users accept to be bound by the terms of use of the UNESCO Open Access Repository (http://www.unesco.org/openaccess/terms-use-ccbysa-en).

\section{Disclaimer:}

The designations employed and the presentation of material throughout this publication do not imply the expression of any opinion whatsoever on the part of UNESCO concerning the legal status of any country, territory, city or area or of its authorities, or concerning the delimitation of its frontiers or boundaries. The ideas and opinions expressed in this publication are those of the authors; they are not necessarily those of UNESCO and do not commit the Organization.

\section{Citation:}

Mihelcic, J.R. 2018. Sludge Management: Biosolids and Fecal Sludge. In: J.B. Rose and B. Jiménez-Cisneros, (eds) Global Water Pathogen Project. http://www.waterpathogens.org (J.R. Mihelcic and M.E. Verbyla) (eds) Part 4 Management Of Risk from Excreta and Wastewater) http://www.waterpathogens.org/book/sludge-management Michigan State University, E. Lansing, MI, UNESCO.

https://doi.org/10.14321/waterpathogens.69

Acknowledgements: K.R.L. Young, Project Design editor; Website Design: Agroknow (http://www.agroknow.com) 


\section{Summary}

Sludge, biosolids, and faecal sludge are generated during management of wastewater and the contents of latrines. The direct disposal of untreated sludge is not desirable because it: 1) has odors, 2) is comprised primarily of water which makes transport and disposal expensive, and 3) contains harmful environmental pollutants and pathogens. Several processes can decrease pathogen concentrations in sludge: 1) stabilization, 2) thickening, 3) dewatering, and 4) other processes that include composting. Stabilization uses biological, chemical, and/or thermal processes to reduce organic matter, water content, and odors and also provides some pathogen reduction. Thickening and dewatering can reduce volume and increase the concentration of total solids. Thickening is performed prior to stabilization while dewatering is the final method of volume reduction before ultimate disposal of stabilized sludge (drying beds and mechanical processes). Other methods of sludge processing including composting, heat drying, and combustion.

Temperature and storage time are the two most important factors in achieving significant pathogen destruction. Moisture content and $\mathrm{pH}$ are also important. Examples of sludge management technologies that can achieve temperatures greater than $45^{\circ} \mathrm{C}$ if properly designed and operated are: 1) composting, 2) thermal treatment, and 3) thermophilic digestion. For lower temperature treatments, pathogen concentrations are reduced but still routinely identified in treated sludge. Other ways to improve pathogen destruction are reducing moisture content by drying (through evaporation, transpiration by use of deep rooted plants, and drainage of water vertically from a drying bed), raising $\mathrm{pH}$, and/or increasing the concentration of unionized ammonia (NH3). Sunlight's role is mostly through supporting desiccation of drying sludge. Biological processes (e.g., digestion, composting) can reduce the volatile organic fraction of sludge; thus, reducing disease vector attraction. Helminth eggs are particularly resistant to treatment, including thermal and chemical treatment. Therefore, in regions where helminth infections regularly occur, it is recommended to first provide treatment in sludge-drying beds, and then to bury the dried sludge to minimize exposure. The World Health Organization also provides recommendations for storage treatment of dried excreta and fecal sludge. They recommend an additional barrier of safety of waiting one month between the time stored excreta is applied to a crop and the time the crop is harvested.
Faecal sludge is a distinct type of sludge that is generated onsite (e.g., discharge to toilet/latrine pits and septic tanks) and is not transported through a sanitary sewer. It has different physical-chemical characteristics than sludge generated at a centralized treatment plant. The service chain for faecal sludge management shows a potential for increased human health risk associated with pathogen exposure during the collection of the material and subsequent transport to a treatment or disposal facility. Thus design and management of toilet/latrine and septic systems must consider safe collection and transport of the contents.

\subsection{Brief Technology Description}

Sludge is generated during primary and secondary treatment of wastewater. "Biosolids" is a word used to describe sludge that receives treatment at a centralized facility and meets land application standards (NRC, 2002). "Fecal sludge" is a term used to describe sludge generated from an onsite sanitation technology that has not been transported in a sanitary sewer. It can be "raw or partially digested, a slurry or semisolid, and results from the collection, storage or treatment of combinations of excreta and blackwater, with or without greywater." (Strande et al., 2014). The fundamental mechanisms of how pathogen levels are reduced in the management of sludge, biosolids, and fecal sludge are similar as are the treatment technologies. Accordingly, for the remainder of this chapter, the word sludge will be used to describe both biosolids and fecal sludge, except in locations where management strategies for a particular sludge type may differ.

The direct disposal of untreated sludge is not desirable because: 1) it has odors associated with it, 2) it is comprised primarily of water which makes transport and disposal more expensive, and 3) it contains harmful environmental pollutants and pathogens (Mihelcic and Zimmerman, 2014). An important point to consider is that in a centralized wastewater treatment plant, while the total volume of sludge is small compared to the total volume of wastewater, sludge management can cost up to 60 percent of the overall operating costs of wastewater treatment (Andreoli et al., 2007). Also, if managed incorrectly and released into the environment without adequate treatment, conventional pollutants and pathogens found in sludge can negate the health and environmental benefits of wastewater treatment. Sludge management is an integral component of centralized or semi-centralized wastewater systems (Figure 1) and onsite systems (shown later in Figure 6), serving cities and small communities alike. Fecal sludge management has also become a distinct area of sludge management with books and conferences devoted to it (e.g., Strande et al., 2014). 


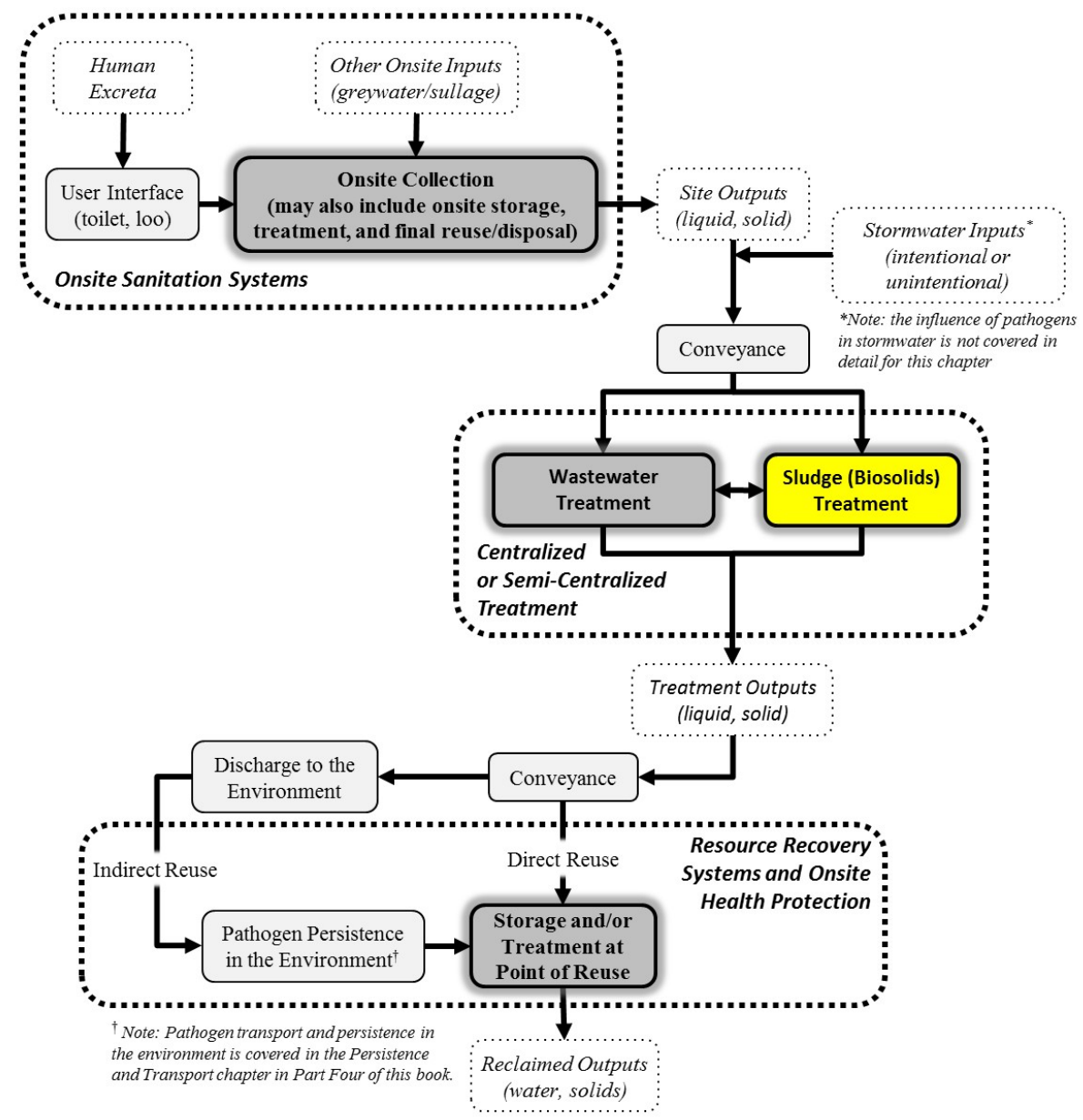

Figure 1. Location of sludge management within the sanitation service chain for a centralized or semi-centralized treatment facility (a figure of the service chain for fecal sludge is provided in Section 5)

There are many technologies to decrease pathogen concentrations in wastewater sludge. These technologies can be broken down into the following processes: 1) stabilization 2) thickening, 3) dewatering, and 4) other processes that includes composting. Examples of technologies associated with these processes are summarized in Table 1. Sludge stabilization typically uses biological and chemical processes to reduce odor, water content, and the presence of pathogenic organisms in sludge. The purpose of dewatering is to reduce water content because sludge associated with primary and secondary treatment of wastewater only has a solids content of half to several percent (sludge is thus mostly comprised of water in its original untreated state). 
Table 1. Processes (and example technologies) to treat wastewater sludge and faecal sludge

Stabilization

Thickening and Dewatering

Other Methods to reduce problems associated with sludge odor and putrescence and the presence of pathogenic organisms. It uses biological, chemical, and/ or thermal processes to reduce organic matter, water content, and odors and also provides some pathogen reduction.

used to dewater sludge which reduces the sludge volume and increase the concentration of total solids. Thickening is performed prior to stabilization while Dewatering is the final method of volume reduction before ultimate disposal of stabilized sludge (drying beds and mechanical processes). Though dewatering processes may result in the reduction of the total number of pathogens, they may also result in an increase in the volumetric concentration of pathogens, due to the reduction of overall volume.

used to dewater sludge, which reduces the sludge volume and increase the concentration of total solids
Biological Digestion (aerobic or anaerobic)

Chemical (e.g., alkaline (lime)) stabilization

Thickening

Mechanical belt presses

Centrifugation

Drying beds

Reed beds

Lagoons

Composting

Heat Drying

Combustion 
For more information about sludge treatment and disposal or reuse, refer to Andreoli et al. (2007), Drechsel et al. (2010), Burton et al. (2014), Oakley and Salguero (2011), Oakley et al. (2012) and Semiyagaa et al. (2015). Strande et al. (2014) provide a comprehensive book on fecal sludge management. Several journal articles (e.g., Dumontet et al., 1999; Jiménez, 2007; Arthurson, 2008; Pepper et al., 2010) provide literature reviews of pathogens present in sludge and their fate by various treatment processes. Historical information on pathogen fate associated with sludge management is available in Feachem et al. (1981, 1983).

\subsection{Inputs and Outputs}

The outputs from sludge management include treated sludge and may also include biogas and other resources. Because treated sludge contains valuable resources (e.g., energy, carbon, nitrogen, and phosphorus), biosolids and fecal sludge are considered an integral part of a resource recovery strategy (e.g., a viable soil amendment if pathogens are reduced to safe levels). A recent study identified potential markets for fecal sludge in two SubSaharan cities (Dakar and Kampala) and concluded feasible uses included drying the sludge as a fuel for combustion, generating biogas from anaerobic digestion, deriving protein from sludge processing to use as animal feed, incorporating sludge as a component in building materials, and using sludge as a soil conditioner (Dienera et al.,
2014). Fecal sludge obtained from processes that first separate urine is still valuable as a soil amendment, though it will contain less of the nutrients, nitrogen and phosphorus. This is because the majority of these two nutrients are present in human urine, and not feces. Biogas generated during anaerobic stabilization consists of approximately $2 / 3$ methane by volume, which if collected and processed safely can provide a local source of energy used for cooking and heating, or in large scale applications, generation of electricity. Because methane is a much more powerful greenhouse-forcing gas than carbon dioxide (on a mass basis), care needs to be taken to ensure that biological stabilization processes are not just simply creating and releasing methane into the atmosphere (Bruun et al., 2014).

Table 2 provides information on the typical mass of sludge generated during primary and secondary wastewater treatment during centralized and onsite treatment. Besides odorous compounds, sludge may have other undesirable components: metals, trace organic chemicals, and pathogens. This chapter is only focused on reduction of pathogens.

Table 2. Sludge generated during specific wastewater treatment processes

\begin{tabular}{|c|c|c|c|}
\hline & $\begin{array}{c}\text { kg Suspended Solids } \\
\text { Sludge Produced / kg COD } \\
\text { Applied }\end{array}$ & $\begin{array}{l}\text { Percent Dry Solids } \\
\text { in Sludge }(\%)\end{array}$ & $\begin{array}{c}\text { Liters of Sludge Produced } \\
\text { / Person-day }\end{array}$ \\
\hline Conventional Primary Treatment ${ }^{\mathrm{a}}$ & 0.35 to 0.45 & 2 to 6 & 0.6 to 2.2 \\
\hline Septic Tank Primary Treatment ${ }^{\mathrm{a}}$ & 0.20 to 0.30 & 3 to 6 & 0.3 to 1.0 \\
\hline $\begin{array}{l}\text { Secondary (i.e., biological) wastewater } \\
\text { treatment }^{\mathrm{a}}\end{array}$ & 0.07 to 0.35 & 0.5 to 4.0 & 0.05 to 6.0 \\
\hline Ventilated Improved Pit (VIP) Toilet & NR & 17 to $23^{b}$ & 0.07 to $0.40^{\mathrm{c}}$ \\
\hline Urine Diverting Toilet & NR & $40^{\mathrm{b}}$ & 0.07 to $0.40^{\mathrm{d}}$ \\
\hline
\end{tabular}

\section{NR: Not Reported}

${ }^{\mathrm{a}}$ Andreoli et al., 2007; ${ }^{\mathrm{b}}$ Strande et al., 2014; ${ }^{\mathrm{c}}$ filling rate reported by Foxan et al. (2011). Franceys et al. (1992) reported solids accumulation rates of 0.11 to $0.25 \mathrm{~L} /$ person-day; ${ }^{\mathrm{d}}$ assumed similar to VIP toilet

Table 3 provides expected concentration ranges of some pathogens present in specific types of wastewater sludge. In one review, Dumontet (1999) reported the following magnitudes of viral and bacterial pathogen concentrations per $\mathrm{kg}$ in untreated sludge: $10^{3}$ (viruses), $10^{6}$ (Salmonella spp.), $10^{7}$ (Shigella spp.), $10^{6}$ (Yersinia spp.), $10^{3}$ (Brucella spp.), and $10^{5}$ (Staphylococcus coagulase positive). The magnitude of the concentrations of specific pathogens in wastewater and sludge is however a function of socialeconomic factors that are specific to a particular community and its health. 
Table 3. Expected range of pathogen concentration in sludge (values obtained from Andreoli et al., 2007)

\begin{tabular}{lcc}
\hline \multicolumn{1}{c}{ Pathogen } & Type of Sludge & $\begin{array}{c}\text { Typical Concentrations } \\
\text { (Number per kg Total Solids) }\end{array}$ \\
\hline Bacteria & Sludge & E+01 to E+07 \\
& Primary sludge & E+03 to E+04 \\
Digested sludge & E+02 to E+03 \\
Helminth eggs & Partially-dewatered sludge & E+01 to E+03 \\
& Partially-dewatered sludge from aerobic & E+02 to E+05 \\
& treatment & E+03 to E+04 \\
Protozoan (oo)cysts & Anaerobic sludge & E+04 to E+06 \\
& Primary sludge & E+04 to E+06 \\
Viruses & Digested sludge & E+01 to E+02 \\
& Dewatered sludge & E+01 to E+05
\end{tabular}

\subsection{Factors Affecting Pathogens in Sludge Management Systems}

During sludge processing, pathogens are inactivated by different mechanisms. These mechanisms will be similar for biosolids and fecal sludge. Figure 2 reviews the major mechanisms that lead to pathogen destruction in four common sludge management technologies. The efficiency of each of these mechanisms is dependent on a number of environmental, design, and operational factors. Temperature and time have been identified as perhaps the two most important factors in achieving significant pathogen destruction during sludge management (Sahlström, 2003). This is shown in the four figures presented in Figure 2.

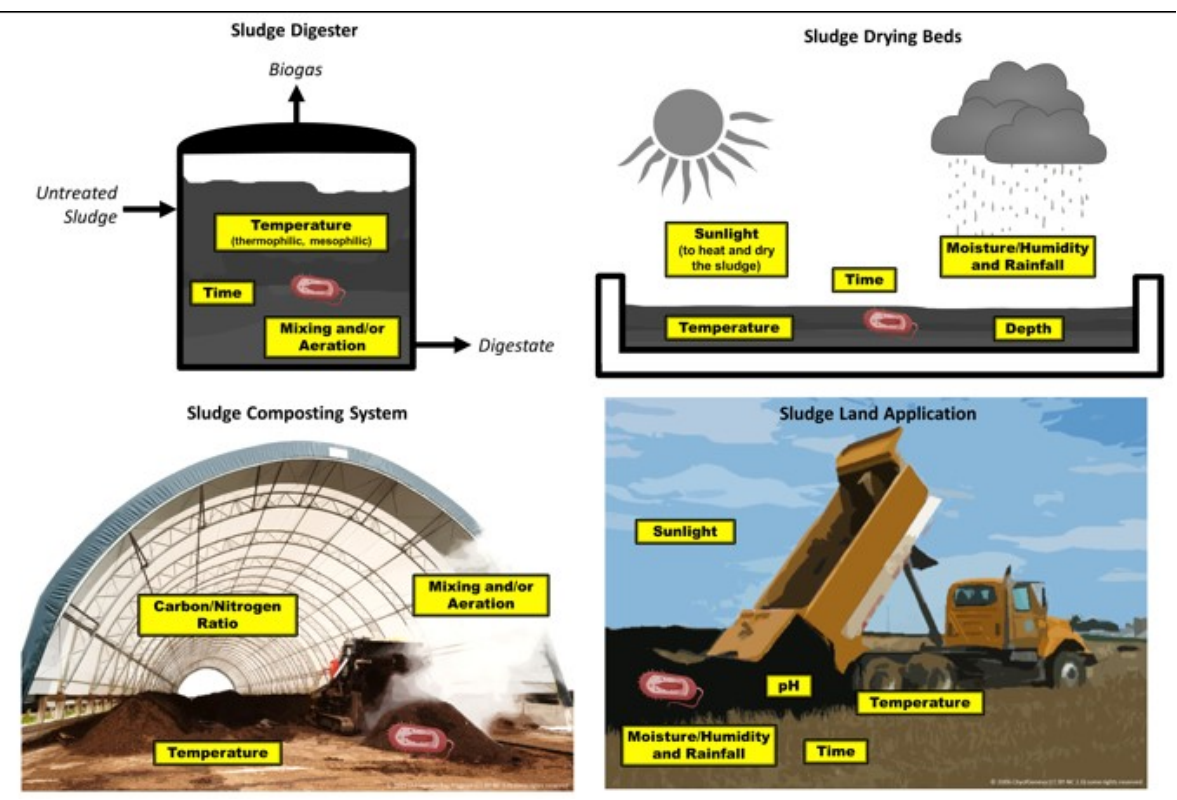

Figure 2. Major factors affecting pathogens in sludge digesters (top left), sludge drying beds (upper right), composting systems (bottom left), and land application systems (bottom right). Photo of composting system @ 2015 Chesapeake Bay Program (CC BY-NC 2.0). Photo of sludge land application system $\odot$ City of Geneva (CC BY-NC 2.0)

Other mechanisms used to promote pathogen destruction during sludge treatment are desiccation (i.e., reducing moisture content by air or heat drying), raising $\mathrm{pH}$, and increasing free (unionized) ammonia $\left(\mathrm{NH}_{3}\right)$ concentration. Because the pKa for the ammonium/ammonia acid base reaction is 9.3, producing unionized ammonia can be achieved by raising the $\mathrm{pH}$, which converts ionized ammonium $\left(\mathrm{NH}_{4}^{+}\right)$to $\mathrm{NH}_{3}$. Addition

of urine and urea have also been proposed as a source of unionized ammonia (Vinnerås, 2007; Trimmer et al., 2016). Biological stabilization processes (e.g., digestion, composting) can reduce the volatile organic fraction of sludge; thus, reducing disease vector attraction and bacterial growth because of loss of available organic substrate (USEPA, 2003). Sunlight's role in decreasing pathogen concentrations in sludge is most likely through supporting desiccation of drying sludge (USEPA, 2003).

Table 4 summarizes some of the important factors and mechanisms for pathogen reduction in sludge shown in Figure 2. A comprehensive book on fecal sludge management also provides discussion of these factors and mechanisms (Strande et al., 2014). Examples of sludge treatment technologies that can achieve temperatures greater than $45^{\circ} \mathrm{C}$ are: 1) composting, 2) heat treatment, and 3) thermophilic digestion. For lower temperature treatments, pathogen concentrations are 
reduced but still routinely identified in treated sludge (Gantzer et al., 2001). Tables 5 and 6 reinforce the importance of temperature in inactivating E. coli and a persistent pathogen such as Ascaris suum ova in sludge digesters. Increasing the $\mathrm{pH}$ of sludge (by lime addition) to levels above 12 is sufficient to reduce many pathogen concentrations to safe levels; however, it has been identified to not be as efficient on treating nematode eggs (which might require storage times as high as 6 months) (Gantzer et al., 2001).

Table 4. Summary of factors and mechanisms for pathogen reduction in sludge

\section{Mechanisms and Factors}

Temperature/Time/Moisture

Alkaline stabilization with quicklime $(\mathrm{CaO})$
Inactivation of pathogens in sludge is a function of temperature, time, and moisture content. The rate of inactivation increases with increasing temperature and decreasing moisture content.

For instance, treatment at lower temperatures requires more time at the same moisture content to achieve the same level of pathogen reduction.

Application of $\mathrm{CaO}$ to dewatered sludge to raise the $\mathrm{pH}>12$ causes an exothermic reaction with temperatures exceeding $50^{\circ} \mathrm{C}$
Evidence of Pathogen Vulnerability

Long-term storage of dewatered sludge can inactivate all pathogens at the following temperatures (WHO, 2006): 2 to $20^{\circ} \mathrm{C}: 1.5$ to 2 years

- Reduces all pathogens to low levels 20 to $35^{\circ} \mathrm{C}:>1$ year

- Substantial to total inactivation of viruses, bacteria, and protozoa.

- More or less complete inactivation of helminths after 1 year. Viruses

- Poliovirus has been inactivated $3.0 \log _{10}$ in laboratory thermophilic digesters $\left(49\right.$ to $55^{\circ} \mathrm{C}$ ) (Aitken et al., 2005). Protozoa

- High temperatures cause more rapid inactivation of Cryptosporidium (oo)cysts (Reinoso et al., 2008) Helminths

- Temperature is the most important factor for the inactivation of helminth eggs in thermophilic anaerobic digesters. A $3.0 \log _{10}$ removal of Ascaris was documented at temperatures of 53 and $55^{\circ} \mathrm{C}$ (Aitken et al., 2005).

- Ascaris in composted excreta has been inactivated in a solar thermal post-treatment unit at the following levels (Darimani, 2015): $2.0 \log _{10}: 2$ hours at $50^{\circ} \mathrm{C}$ and $50 \%$ moisture $3.0 \log _{10}: 3$ hours at $60^{\circ} \mathrm{C}$ and $50 \%$ moisture

Alkaline stabilization, if properly engineered and operated, can inactivate viral, bacterial, protozoan and helminthic pathogens (Burton et al., 2014).

Table 5. E. coli removal in mesophilic anaerobic digesters (summarized by Horan et al., 2004)

\begin{tabular}{|c|c|c|}
\hline Operating Conditions & Removal of $E$. coli $\left(\log _{10}\right.$ units) & Reference \\
\hline $\begin{array}{l}14 \text { days retention time, } \\
10^{\circ} \mathrm{C}\end{array}$ & 0.5 & Le et al., 2002 \\
\hline $\begin{array}{l}14 \text { days retention time, } \\
25^{\circ} \mathrm{C}\end{array}$ & 1.0 & Le et al., 2002 \\
\hline $\begin{array}{l}\text { Primary sludge } \\
\text { digestion in full-scale } \\
\text { plants in England }\end{array}$ & 1.0 & Le et al., 2000 \\
\hline $\begin{array}{l}\text { Secondary sludge } \\
\text { digestion in full-scale } \\
\text { plants in England }\end{array}$ & 1.5 & Le et al., 2000 \\
\hline $\begin{array}{l}35 \text { to } 37^{\circ} \mathrm{C} \text { for } 20 \text { days } \\
\text { HRT in France }\end{array}$ & 1.5 & Gantzer et al. 2001 \\
\hline $\begin{array}{l}\text { Survey of primary } \\
\text { sludge facilities in } \\
\text { England }\end{array}$ & 1.35 to 3.36 & Humphrey, 1999 \\
\hline
\end{tabular}


Table 6. Time needed to reach 99\% (T99) inactivation of Ascaris suum ova during anaerobic digestion of sludge under various temperatures (from Manser et al., 2016)

\begin{tabular}{|c|c|c|c|}
\hline & Digestion Temperature $\left({ }^{\circ} \mathrm{C}\right)$ & T99 & Reference \\
\hline 10 & & $\begin{array}{c}> \\
2,555 \\
\text { days }\end{array}$ & $\begin{array}{c}\text { Sanguinetti } \\
\text { et al. } \\
(2005)\end{array}$ \\
\hline 20 & & $\begin{array}{c}450 \\
\text { days }\end{array}$ & $\begin{array}{l}\text { Pecson et } \\
\text { al. (2007) }\end{array}$ \\
\hline 30 & & $\begin{array}{l}180 \\
\text { days }\end{array}$ & $\begin{array}{l}\text { Pecson et } \\
\text { al. (2007) }\end{array}$ \\
\hline 35 & & $\begin{array}{c}22 \\
\text { days }\end{array}$ & $\begin{array}{l}\text { Manser et } \\
\text { al. (2015) }\end{array}$ \\
\hline 40 & & $\begin{array}{c}5 \\
\text { days }\end{array}$ & $\begin{array}{l}\text { Pecson et } \\
\text { al. (2007) }\end{array}$ \\
\hline 50 & & $\begin{array}{l}110 \\
\text { min } \\
\text { to } 4 \\
\text { days }\end{array}$ & $\begin{array}{c}\text { Pecson et } \\
\text { al. (2007); } \\
\text { Popat et al. } \\
\text { (2010) }\end{array}$ \\
\hline
\end{tabular}

The biological and chemical treatment of sludge does not necessarily inactivate all pathogens. Helminth eggs are particularly resistant to sludge treatment processes. For example, Gaspard et al. (1995) found that helminth eggs in treated sludge from wastewater treatment plants in France contained the following percentages of viable eggs: 1) anaerobic digestion: $66 \%, 2$ ) composting: $25 \%$, and 3) lime treatment: $66 \%$. In addition, Sahlstrom et al. (2003) found the following percentages of Salmonella still remaining in treated sludge from eight wastewater treatment plants in Sweden: 1) mesophilic anaerobic digestion: 58\%, 2) thermophilic anaerobic digestion: $12.5 \%$, and 3 ) composting: $12.5 \%$.

\subsection{Design, Operation and Maintenance Guidelines for Pathogen Reduction in Sludge Management Systems}

Of the four sludge stabilization technologies discussed in this chapter, composting of sludge after biological stabilization (e.g., anaerobic digestion) and heat pelletization $\left(30-37^{\circ} \mathrm{C}\right.$ for $10-20$ days following by low pressure oxidation drying systems) have been found to provide the lowest levels of culturable fecal indicators and pathogen genomes. These two technologies were followed by temperature-controlled anaerobic digestion and finally mesophilic anaerobic digestion (Viau and Peccia, 2009). Thermophilic biological processes such as aerobic digestion and composting raise the temperature of the sludge while biological processes like anaerobic digestion may have heat added to achieve thermophilic temperatures (sometimes by burning the methane found in the biogas output). Sludge may also be disposed of in a sanitary landfill. While disposal may be a safe management strategy, it limits opportunities for resource recovery. 


\subsection{Aerobic and Anaerobic Sludge Digestion}

Digestion is a common method of sludge stabilization. It is employed by large treatment plants, households, and small to large farms. During digestion, the organic and odorous fraction of the sludge is stabilized by microorganisms that degrade the volatile organic fraction of the sludge in the presence or absence of oxygen. Digesters can be fed continuously or intermittently. Low rate (i.e., passive) digesters are typically mixed and operated at ambient temperature while high rate (i.e., active) digesters are mixed and may be aerated and/or heated. Sludge derived from a digester may be further processed by other treatment methods discussed in this chapter (e.g., dewatering technologies).

An important point of digester design and operation for pathogen reduction is that digesters can be operated under mesophilic (temperature range of $\approx 25-40^{\circ} \mathrm{C}$ ) or thermophilic (temperature range of $>40^{\circ} \mathrm{C}$ ) conditions. In general, because of its higher temperature, thermophilic digestion is more efficient at reducing pathogen levels than mesophilic digestion. It is in fact recommended that for anaerobic digesters operated in the temperature range of $35-55^{\circ} \mathrm{C}$, the solids retention time (referred to as SRT) of the sludge be at least 15 days while for $20^{\circ} \mathrm{C}$ the solids retention time would need to increase to 60 days (USEPA, 1994). To provide an additional general point on the importance of temperature in pathogen removal, the $t_{90}$ (the amount of time it takes for $90 \%$ or $1 \log _{10}$ reduction) for bacteria ranges from hours to days for thermophilic digestion and from weeks to months for mesophilic digestion (Sahlström, 2003). When operated with the same retention times, batch operations generally result in better pathogen removal than continuous flow operations, due to the fact that continuous flow operations result in partially-mixed conditions with short-circuiting that may cause some of the pathogens to remain in the reactor for much less than the average retention time (Manser et al., 2015).

The literature is not clear if the amount of volatile fatty acids (VFA) present in sludge has an impact on the fate of pathogens. For example, VFAs were shown to inactivate Shigella by more than $6.5 \log _{10}$ units in night soil with 9,000 mg/L VFAs after 18 days at pH 6.5 (Kunte et al., 2000) and Salmonella by more than $7 \log _{10}$ units in an anaerobic sludge digester with 5,000 mg/L VFAs after 12 days at $\mathrm{pH} 6$ (Kunte et al., 1998). Ascaris eggs were completely inactivated at pH 5 - 6 when exposed to VFAs for only 20 hours in distilled water, but in sewage sludge, $82 \%$ of the eggs still remained viable after a week (Butkus et al., 2011). Typical reductions in the concentrations of fecal indicator organisms during digestion are reported to be approximately 1-2 $\log _{10}$ units (Farrell et al., 1988).

\subsubsection{Aerobic digestion}

In aerobic digestion, a batch or continuous flow system is set up that provides air to the sludge via mixing or some form of mechanical aeration. These reactors are typically not heated but thermophilic bacteria that degrade organic carbon during the process produce heat. A batch operated aerobic digester can require aeration for up to 2-3 weeks. Aerobic digestion performed at a solids retention time of 40 days and temperature of $20^{\circ} \mathrm{C}$ or a solids retention time of 60 days and lower temperature of $15^{\circ} \mathrm{C}$ is expected to reduce bacterial and viral pathogens by $90 \%$ (USEPA, 2003). As might be expected, thermophilic aerobic digestion has much better removal of pathogenic bacteria, viruses, and parasites than mesophilic anaerobic digestion (Kabrick and Jewell, 1982).

\subsubsection{Anaerobic digestion}

Anaerobic digestion is a more common type of sludge digestion. It takes place in an enclosed reactor (that may or may not be heated). In an anaerobic environment void of oxygen, organic material is reduced to carbon dioxide (approximately $1 / 3$ of the gas volume), methane (approximately $2 / 3$ of the gas volume), and ammonia. The three-step biochemical process includes hydrolysis, acidogenesis and acetogenesis, and methanogenesis. In a low-rate system, mixing is typically caused by gas bubbles that rise through the sludge and influent sludge is added intermittently. A high-rate system employs active mixing and controlled temperatures to increase the rate of sludge stabilization and pathogen inactivation (USEPA, 2003).

While a 1 to $2 \log _{10}$ reduction has been observed for fecal coliforms and heterotrophic bacteria during anaerobic digestion (Chauret et al., 1999), Clostridium perfringens, Enterococcus sp., and Giardia cysts are reported to have no statistically significant reduction during anaerobic digestion at $36^{\circ} \mathrm{C}$ with a retention time of 20 days. (Soares et al., 1994; Sykora et al., 1991; Chauret et al., 1999). Chauret et al. (1999) also reports the reduction of $0.09 \log _{10}$ units of somatic coliphages during anaerobic digestion.

Infectious virus particles are reduced approximately 1 $\log _{10}$ during full-scale mesophilic anaerobic digestion $\left(36^{\circ} \mathrm{C}\right)$ in a primary digester operated at a hydraulic residence time of 14 days followed by a secondary digester that increased the contact time by an additional 9 days. Pepper et al. (2010) reported that over a 17-year period study, the performance of eighteen full-scale mesophilic anaerobic digesters in the U.S. (serving populations of $>0.5$ million) the average removal of enteric viruses was $94.4 \%$, Salmonella was $97.6 \%$, fecal coliforms was $98.9 \%$, and total coliforms was $98.8 \%$. If the temperature is raised to $50^{\circ} \mathrm{C}$ virus inactivation is reported to reach $99.99 \%$ (Sanders et al., 1979).

\subsubsection{Small scale anaerobic digesters}

Small scale anaerobic digesters can be constructed from brick or plastic materials (Figure 3). They are the most common anaerobic digesters used by farms and households in low-income countries. They are typically operated under ambient conditions and fed on an intermittent basis with agricultural wastes (e.g., manure), which can be mixed with human waste. Because these 
systems produce methane (which has $\approx 25$ times the global warming potential of carbon dioxide), before these systems are implemented, it should be ensured that the resulting demand for biogas will be $\geq$ gas production and systems are regularly maintained to ensure no leakage of biogas to the atmosphere.
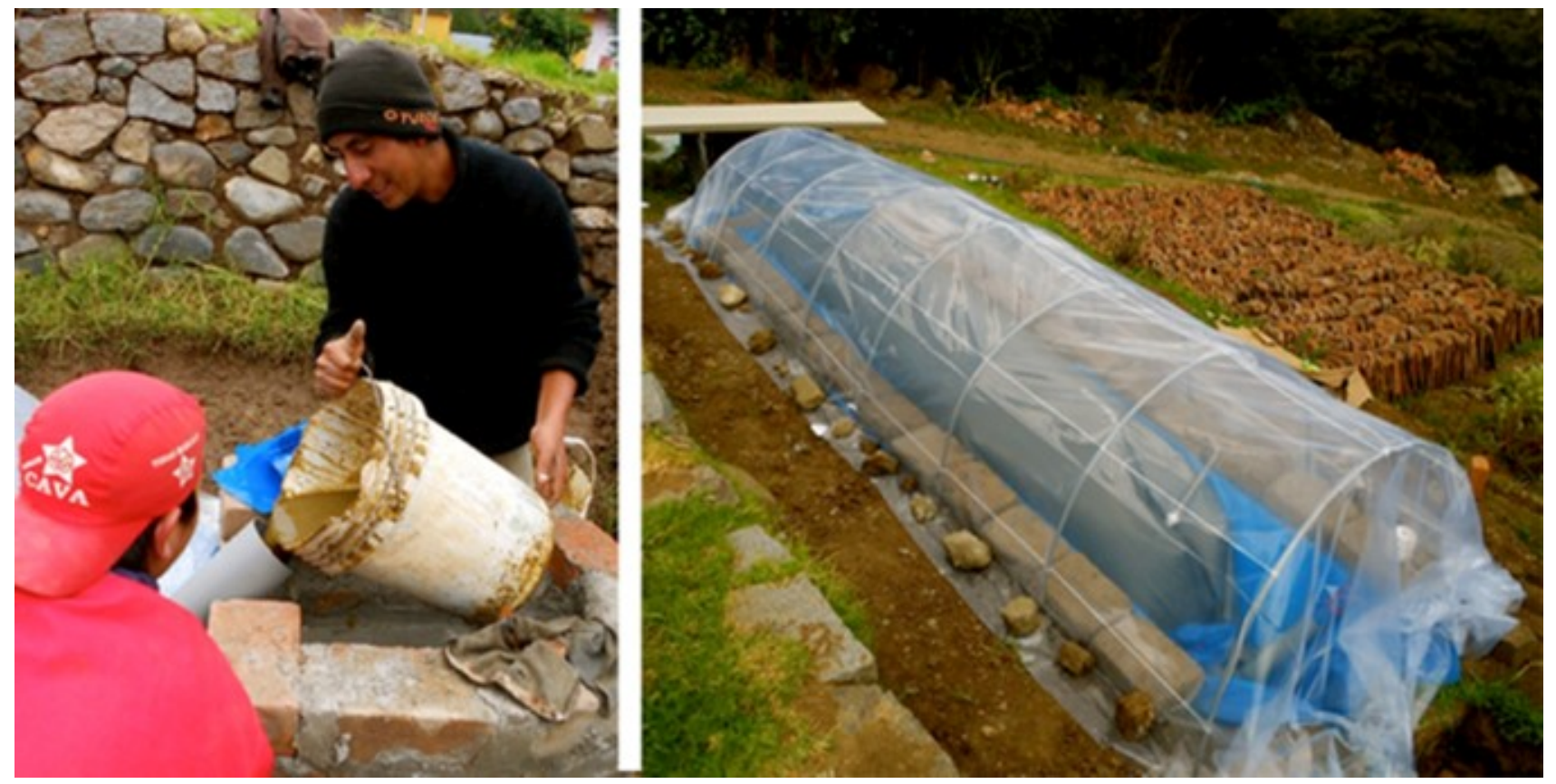

Figure 3. Left) Filling a tubular anaerobic digester with sludge. Right) Tubular digester (dark cylindrical tube) located inside a clear plastic covering to promote higher temperature (photos provided by Danielle DeVuyst with permission)

However, use of anaerobic digesters operated in this manner may not be sufficient to safely inactivate persistent human pathogens such as Ascaris spp. Because these digesters are typically fed intermittently, a user only has control over the solids retention time and feeding interval. It is expected that these reactors also operate at lower temperatures which may be near ambient. For example, one study observed the temperature of an operating tubular biodigester in Costa Rica that was fed swine manure to be near ambient temperature $\left(21-24^{\circ} \mathrm{C}\right)$ (Kinyua et al., 2016).

Kinyua et al. (2016) also concluded that temperature and volatile fatty acid concentration were the main factors contributing to Cryptosporidium parvum and Giardia lamblia inactivation in tubular digesters. They reported a $1.56( \pm 0.24) \log _{10}$ reduction for G. lamblia and $0.55( \pm$ 0.01) $\log _{10}$ reduction for $C$. parvum over a 24-day period at a temperature of $21^{\circ} \mathrm{C}$ and volatile fatty acid concentration of approximately $300 \mathrm{mg} \mathrm{COD} / \mathrm{L}$.
Manser et al. (2016) developed a mathematical model to estimate the inactivation of Ascaris suum ova in householdscale digesters that are fed on a semi-continuous basis. That work demonstrated two things. First, at $35^{\circ} \mathrm{C}, A$. suum ova inactivation was found to be weakly dependent on feeding frequency (i.e., inactivation only increased slightly, from 61 to $64 \%$ when the feeding interval was increased from 2 to 7 days). In contrast, the model showed that A. suum ova inactivation was more dependent on solids retention time (i.e., inactivation increased from 40 to $73 \%$ when the solids retention time was increased from 15 to 45 days). The second item demonstrated in this study was related to field operation that would result in safe use of treated sludge that contained persistent pathogens such as Ascaris. In this case, regardless of the feeding interval, it is expected that some percent of the digester effluent will remain in the reactor less than the time required to inactivate the ova. Thus, one can't ensure the digester effluent is completely safe in these reactors, unless an upper mesophilic temperature is maintained or the feeding interval exceeds the critical time needed for complete inactivation. 
Literature thus suggests that to ensure inactivation of persistent pathogens like Ascaris spp. in an intermittently fed digester operated under mesophilic conditions, a user may want to add a second digester of equal dimensions and alternate use of the two digesters. The first digester contents would then be left in a storage mode after it reaches capacity, then the user would revert to the second digester. This strategy is typically employed for operation of dual compost latrines (Mehl et al., 2011). It has also been suggested that in single state digesters with a fixed solids retention time, differences in reductions of bacteria and viruses may occur if the reactor is operated using a "draw down, then fill" feeding protocol versus a "fill, then draw down" feeding protocol (Farrell et al., 1988). In that study, the impact of feeding protocol was observed to be greater for bacterial indicators than viruses (i.e., 1-1.5 $\log _{10}$ difference for bacterial indicators versus $0.24 \log _{10}$ difference for viruses). Effluent from these reactors can also be further treated in sludge-drying beds or human exposure can be reduced by burying sludge to reduce health risks by minimizing exposure (as discussed in the Conclusions).

\subsection{Chemical Treatment}

Chemical treatment can consist of adding an alkaline material or ammonia to sludge. The most typical chemical treatment method is to stabilize sludge by adding an alkaline material such as quicklime (i.e., calcium oxide or $\mathrm{CaO}$ ), hydrated lime (i.e., calcium hydroxide or $\mathrm{Ca}(\mathrm{OH}) 2$ ), lime containing kiln dust, or fly ash with the sludge. The kg of hydrated lime required per $1,000 \mathrm{~kg}$ of dry sludge to raise the $\mathrm{pH}$ above 12 is reported by Malina (1993) and averages $110 \mathrm{~kg}$ for primary sludge, $270 \mathrm{~kg}$ for activated sludge, and $170 \mathrm{~kg}$ for anaerobic digested sludge.
The best removal of pathogens with addition of alkaline material is obtained if the $\mathrm{pH}$ is raised to at least 12 for 72 hours (Andreoli et al., 2007). Long term storage of the sludge treated in this manner requires the $\mathrm{pH}$ to remain above 12 to ensure there is no regrowth of pathogenic organisms. In full scale study in France, no viable enterovirus or genome was detected in sludge treated after mechanically mixing with quicklime at a proportion of $50 \%$ dry matter to the biological sludge, which has previously undergone thickening and dehydration (Monpoeho et al., 2004).

Aqueous phase free ammonia is lethal to microorganisms. It is found in digesters, especially at higher $\mathrm{pH}$ and temperatures. Pathogens can also be reduced by adding ammonia directly to the sludge, by use of urea or urine. Aqueous phase free ammonia greater than $80 \mathrm{mg} \mathrm{NH} / \mathrm{L}$ has been reported to be lethal to Ascaris suum ova (Cruz-Espinoza et al., 2012; Pecson et al., 2007; Nordin et al., 2009). This technology has been proposed for management of fecal sludge (e.g. Trimmer et al., 2016).

\subsection{Composting}

The composting process is discussed by Andreoli et al. (2007) and Strande et al. (2014). Andreoli (2007) and Mihelcic et al. $(2009,2014)$ provide examples on design and calculation of the proper mixture to achieve a sufficient carbon-to-nitrogen ratio. Composting can be performed using one of three methods: 1) aerated static pile, 2) invessel, and 3) windrow. Windrow is the less complex and more traditional process. Composting has relatively low capital costs, but it requires a larger amount of land area and may generate odorous air if not properly aerated. A video of composting sludge with plant waste using mechanical turning is shown here: https:// www.youtube.com/watch?v=3RzPIuSNykE. Compost can also be turned manually. 


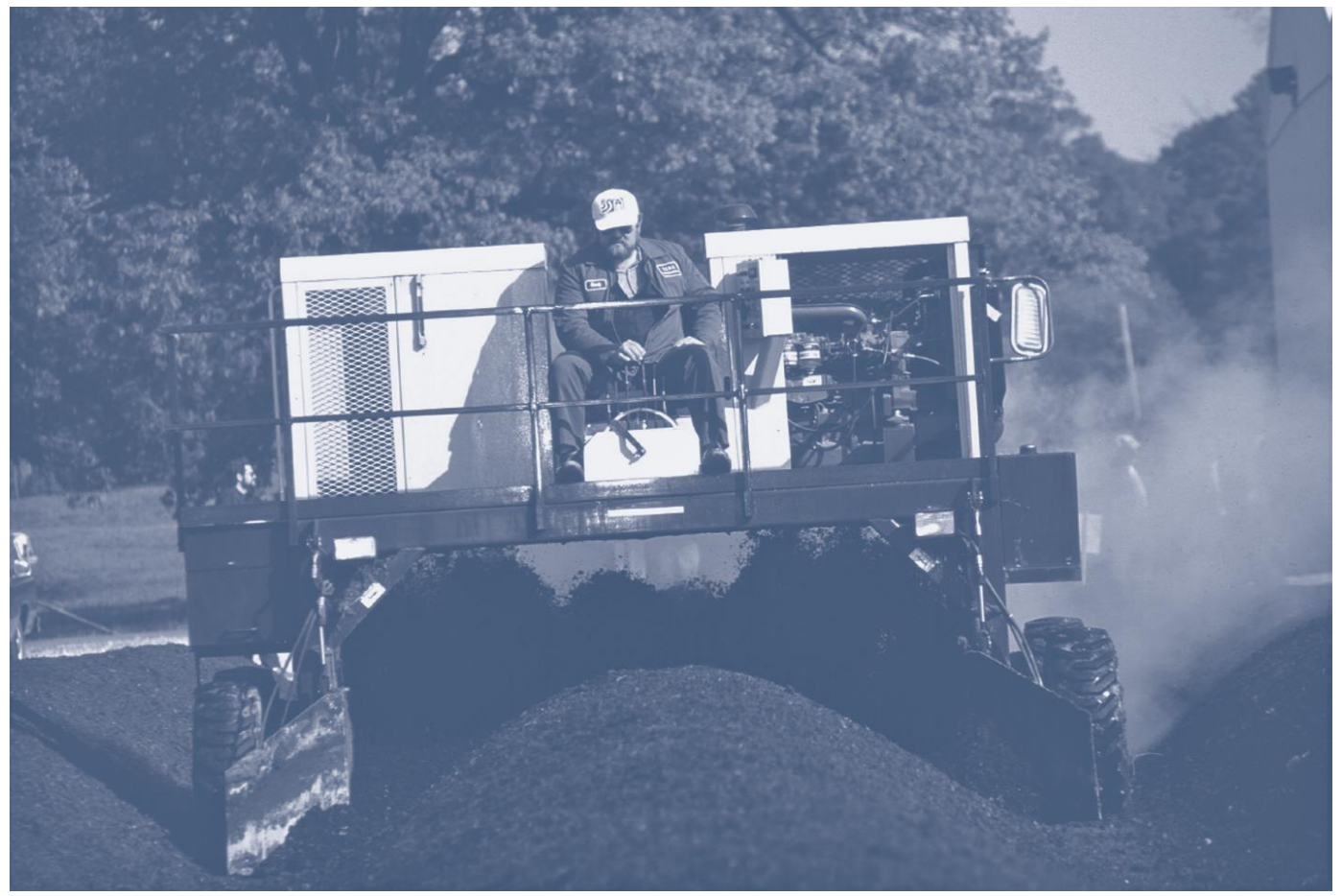

Figure 4. Windrow composting allows for mixing of the components (photo from U.S. Department of Agriculture, Agricultural Research Service Information Staff). The figure shows the composting of plant waste, not sludge; however, the principle is the same).

During windrow composting, a mixture of sludge and bulking agents is placed in rows (called windrows) $1-1.8 \mathrm{~m}$ high and 2-2.5 m wide. The windrows are mechanically turned at regular intervals for a minimum of 15 days (USEPA, 1994). Samples are then stabilized further so the total time of composting and final stabilization may be 50-90 days.

During the composting process, dewatered sludge (Andreoli et al. (2007) suggests a solids concentration of $>$ $35 \%$ ) is mixed with bulking agents (e.g., municipal bulking agents of market, house, and park waste) and microorganisms degrade organic carbon in the compost pile and in the process generating heat. This thermophilic process can attain temperature of up to $80^{\circ} \mathrm{C}$ (ideal temperatures are $55-60^{\circ} \mathrm{C}$, higher temperature and increased contact time result in better destruction of pathogens). Temperatures of $40-60^{\circ} \mathrm{C}$ can be achieved within the first three days (Andreoli et al., 2007). As the readily available organic carbon is degraded, temperatures will fall to $55^{\circ} \mathrm{C}$ or less. One recommendation to reduce pathogens during windrow composting of sludge is to maintain a temperature of $\geq 55^{\circ} \mathrm{C}$ for at least 15 days while turning the windrow at least five times (USEPA, 1994). Maintaining an appropriate $\mathrm{pH}$ is usually not a critical factor if the carbon-to-nitrogen ratio is adequately set
(Fernandes, 2000). One issue not well studied is whether these higher temperatures are achieved in small scale composting operations that don't employ mechanical mixing.

The key to increasing destruction of pathogens during composting is to ensure the thermophilic composting process achieves higher temperature by: 1) maintaining a sufficient supply of oxygen (through static or mechanical/manual aeration), 2) maintaining moisture content between 50-60\%, and 3) raising and maintaining the carbon-to-nitrogen ratio to 20-30:1. Important to successful operation is the fact that temperature and moisture content are relatively easy parameters to monitor. In addition, because the heat produced during the composting process is lost to the surrounding environment, higher compost temperatures may be more difficult to maintain in cooler climates. Andreoli et al. (2007) report that batch composting systems require $12-30 \mathrm{~m}^{3}$ of air per hour per kg of dry mixture at the beginning of the process. This rate of aeration may reach as high as $190 \mathrm{~m}^{3}$ of air per hour per kg of dry mixture as the thermophilic organisms grow. In natural aerated systems, it is recommended to mix the contents at least five times while the organics are in their thermophilic growth phase. 
Because municipal wastewater sludge and feces have a carbon-to-nitrogen ratio of 5-10:1, carbon rich materials (i.e., bulking agents) are added to create an appropriate mixture. Examples are provided in Andreoli et al. (2007) and Mihelcic et al. (2009) on how to achieve appropriate mixtures of sludge and other additives. These additives also provide better porosity to facilitate aeration of the compost pile. Carbon rich bulking agents can be municipal wastes such as market, yard, and park waste but may also include agriculture and industrial byproducts such as wood chips, wood bark, sawdust, straw, and rice hulls. Carbon-nitrogen ratios for different bulking agents are available in references mentioned earlier and on-line. Fecal sludge from composting latrines need to be carefully monitored for presence of pathogens as many latrines, as operated currently, may not achieve temperature much greater than ambient (see Mehl et al., 2011). Thus post treatment of fecal sludge from composting latrine by increasing temperature has been shown to further reduce virus and Ascaris concentrations (Darimani et al., 2015).

Bacterial and viral pathogens can be reduced 1-2 $\log _{10}$ units if composted at $40^{\circ} \mathrm{C}$ or higher for up to 5 days. Reduction of bacterial indicators as high as $2-5 \log _{10}$ may be achieved in composting (Sidhu and Toze, 2009). It is beneficial that for 4 hours during this 5-day period the temperature of the pile exceeds $55^{\circ} \mathrm{C}$ (USEPA, 2003). In one study, no enteroviruses were cultured from sludge that was composted for 3-4 weeks (at temperatures that ranged from $30-68^{\circ} \mathrm{C}$ ) and then left for a further 3 months in a maturation rack (Monpoeho et al., 2004). Insufficient research on the fate of helminths and protozoa in sludge composting systems was identified for this chapter.

Fecal sludge has been treated using vermicomposting. Vermicomposting consists of using worms that grow on the fecal sludge and produce a residue referred to as vermicompost that is reported to be high in nitrogen and phosphorus. Moisture levels much be maintained at 65-85\% by addition of dry bulking agents and treatment time can exceed three months (Semiyaga et al., 2015). Vermicomposting has been reported to reduce pathogen levels found in wastewater biosolids. For example, a field experiment using vermicomposting to treat wastewater biosolids that was applied in windrows ( $6 \mathrm{~m}$ long by $1.5 \mathrm{~m}$ wide and $20 \mathrm{~cm}$ deep). Worm biomass was then added at a ratio of 1:1.5 wet weight earthworm biomass to biosolids. In that particular study the following reductions were observed: $6.4 \log _{10}$ reduction in fecal coliforms, $8.6 \log _{10}$ reduction of Salmonella spp., $4.6 \log _{10}$ reduction in enteric viruses, and $1.9 \log _{10}$ reduction in helminth ova (Eastman et al., 2001).

\subsection{Thermal Treatment}

Thermal treatment (i.e., heat drying) can be performed on primary or stabilized sludge. Treatment of fecal sludge by mechanical dewatering and thermal drying can be followed by pelletizing to produce a final product that can be used as a soil conditioner and fertilizer (Strande et al., 2014). It is feasible when performed on dewatered sludge and if the influent solids content is $15-30 \%$ solids. Reducing water content prior to heat drying is very important because 2,744 kJ of energy are required to evaporate $1 \mathrm{~kg}$ of water contained in sludge (Andreoli et al., 2007). Thermal treatment can also result in reduction of sludge volume, reduced storage and transport costs. Also, no special equipment is required for land application of the processed biosolids. However, thermal treatment is an incineration process that requires input of external energy. High temperatures can be reached in thermal treatment processes such as fluidized bed dryers and drum dryers (Table 7) and will ensure the sludge is virtually free of pathogens and meets health standards for less restricted land applications. However, the temperatures reached in other systems, such as belt dryers, may not necessarily be high enough to destroy all types of pathogens (Figure 5), given the short amount of time sludge is retained in these systems (typically $<1$ hour).

Table 7. Typical temperatures achieved in common thermal treatment technologies for sludge (data from Burton et al., 2014)

Thermal Treatment (Heat Drying Technology
Typical Operation

Temperatures (ㄷ)
Belt Dryer

$<90$

Fluidized Bed Dryer

120

Other Direct Dryers
370 


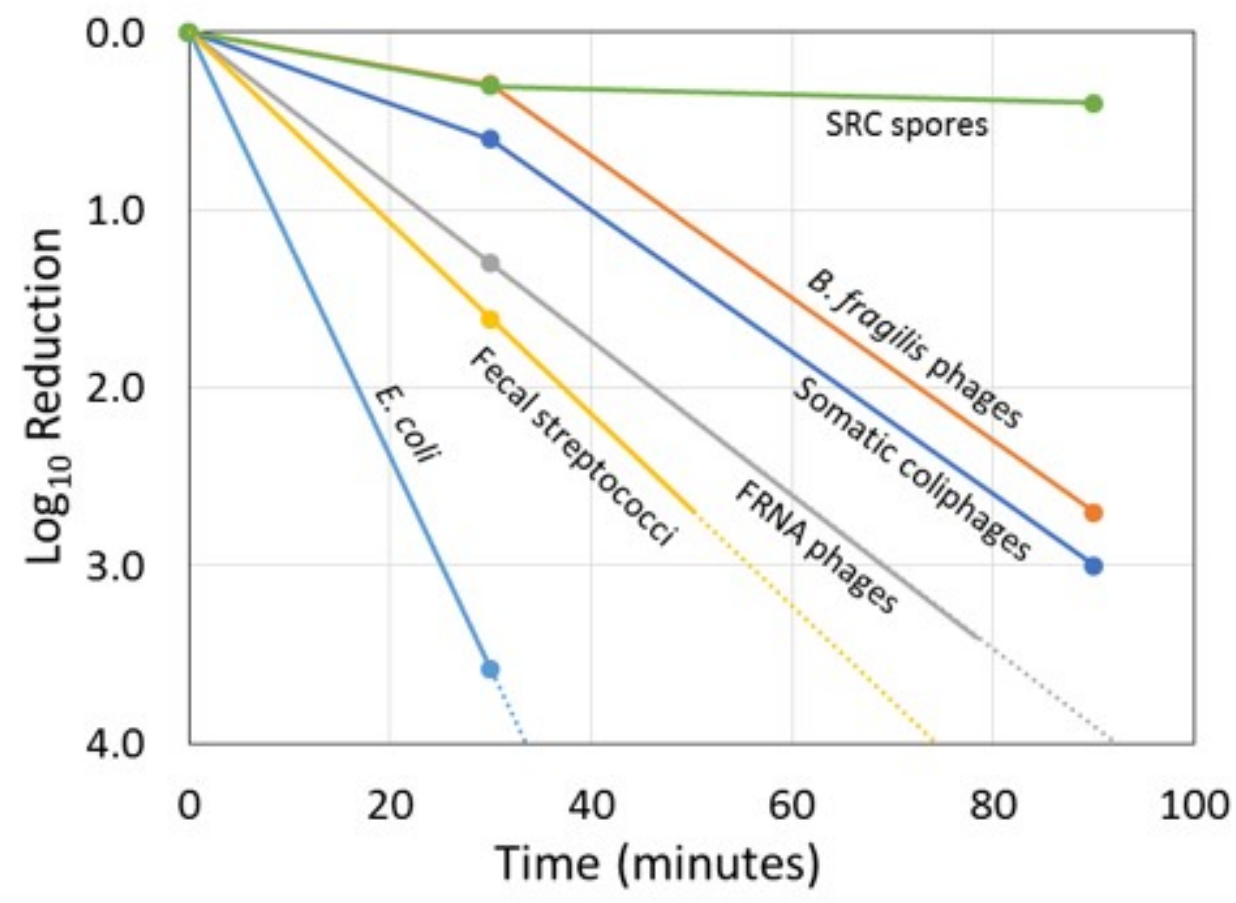

Figure 5. Reduction of bacterial and viral pathogen surrogates in sludge during thermal treatment at $80^{\circ} \mathrm{C}($ data obtained from Mocé-Llivina et al. 2003).

\subsection{Thickening and Dewatering}

Thickening of sludge has been applied to sludge associated with primary treatment, activated sludge, trickling filter processes, and fecal sludge. Dewatering processes and sludge drying are applied to digested sludge (Andreoli et al., 2007). Sludge drying can be applied to any type of sludge.

\subsubsection{Thickening}

The purpose of sludge thickening is to reduce the water content of the sludge and the inherent time expense associated with transporting or thermally treating the water found in sludge. Another reason to reduce the water content of sludge is to decrease the volume of sludge required for land application or disposal. Sludge thickening is typically accomplished by: 1) gravity thickening and 2) dissolved air flotation thickeners. Sludge thickening does not reduce water content enough that it would be expected to inactivate pathogens to any significant manner.

A gravity thickener looks similar to a circular gravity sedimentation tank. The influent sludge is applied to the center and thickened sludge is removed from a withdrawal mechanism located in the bottom of the tank. Design of a sludge thickener is based on solids loading rate ( $\mathrm{kg}$ total solids (TS) $/ \mathrm{m}^{2}-\mathrm{d}$ ) and hydraulic loading $\left(\mathrm{m}^{3} / \mathrm{m}^{2}-\mathrm{d}\right.$ ) (Andreoli et al., 2007). Dissolved air flotation technologies are typically applied to sludge derived from the activated sludge process or in treatment plants that incorporate biological phosphorus removal. In this process, air is forced into the liquid sludge under high pressure. As depressuration occurs, the dissolved air forms gas bubbles that rise to the surface, carry particulates to the surface where they can be skimmed off.

No relevant data on pathogen inactivation during sludge thickening processes was identified, and it is assumed that this process makes a negligible change in the levels of pathogens in sludge.

\subsubsection{Mechanical dewatering}

Mechanical dewatering methods include technologies such as a: 1) belt filter press and 2) centrifuge. Their purpose is to reduce the water content of sludge but not enough that they would be expected to inactivate pathogens. A belt filter press is a mechanical device where sludge is added to a moving belt at ambient temperatures and that is squeezed to remove water. A centrifuge consists of a bowl where solids are moved to the wall by centrifugal force and scraped out by a screw conveyor (Mihelcic and Zimmerman, 2014; Strande et al., 2014).

A study from five treatment plants in the U.K. (Monteleone et al., 2004) reported that for mesophilic anaerobically digested sludge that was dewatered by mechanical methods, most of the centrifuge dewatering systems concentrated E. coli in the sludge and E. coli concentrations did not increase when the sludge was dewatered by a belt filter press. Variations in E. coli concentrations across different mechanical water systems that may be dependent on the origin of the sludge and the specific dewatering process. Centrifugation appeared to increase $E$. coli concentrations by a little over $1 \log _{10}$ unit while a belt filter process was found to have a similar reduction in E. coli (Monteleone et al., 2004). It was 
believed the increases in centrifuge indicator counts suggests that physical forces during dewatering cause disruption of floc structures which releases microorganisms associated with solid particles.

A quantitative microbial risk assessment (QMRA) that accounted for rotavirus, adenovirus, haemorrhagic E. coli, Salmonella, Giardia and Cryptosporidium was performed at a Swedish $12,500 \mathrm{~m}^{3} / \mathrm{d}$ treatment plant that contained tertiary wastewater treatment and mesophilic sludge digestion. The QMRA showed the greatest individual health risk from a single exposure was to workers exposed to aerosols produced at a belt press used for sludge dewatering (virus infection risk $=1$ ). The largest community impact was determined to arise if children ingested sludge at an unprotected storage site (Westrell et al., 2004).

\subsection{Dewatering by Drying}

\subsubsection{Sludge drying beds}

Dewatering of sludge can also occur through water evaporation, plant transpiration, or vertical transport of water out of a layer of sludge spread over a drainage layer. There are many technologies that employ dewatering by these three mechanisms. Some examples are 1) convection drying, 2) contact drying, 3) open sludge drying beds, 4) reed beds, and 5) solar drying. Because they utilize similar fundamental properties, not all technologies are described here. Dewatering technologies are expected to reduce bacteria levels by $2 \log _{10}$ units and pathogenic virus concentrations by $1 \log _{10}$ unit (USEPA, 2003). To assist operation of dewatering technologies discussed in this chapter, Table 8 provides information on how to interpret visually inspected dewatered sludge in regards to the moisture content. Unfortunately, this visual inspection of dried sludge does not provide sufficient insight on pathogen destruction.

Table 8. The meaning of visually inspected sludge summarized (from Imhoff and Hess (1966) using Andreoli et al., 2007). Sludge changes from a liquid to a solid at $18-20 \%$ solids.

\begin{tabular}{lcc}
\hline $\begin{array}{lc}\text { Visual } \\
\text { Inspection }\end{array}$ & $\begin{array}{c}\text { What it } \\
\text { means }\end{array}$ \\
$\begin{array}{l}\text { Dry sludge } \\
\text { with scarce }\end{array}$ & $\begin{array}{c}\text { Well-digested } \\
\text { sludge with } \\
\text { and thin }\end{array}$ & low water \\
cracking & content \\
Large & Digested \\
number of & sludge with \\
medium-sized & high water \\
cracks & content \\
& Poorly \\
Small & digested \\
quantities of & sticky \\
wide cracks & sludge, \\
& requires a \\
& long drying \\
& period
\end{tabular}

Sludge drying removes water by evaporation, transpiration by use of deep rooted plants, and transport of water vertically from a drying bed to an underlying drainage layer. Sludge dried in this manner may have been pretreated (i.e., stabilized) prior in an aerobic or anaerobic reactor. Sludge is placed in layers not exceeding $20-30 \mathrm{~cm}$ over a drainage layer and supporting foundational layer until the solids content is reduced to $30 \%$. A mechanical or manual system can be used to turn the sludge. The drying bed may be lined with sand layers on top of concrete, and be open or closed to protect against rainfall. Greenhouses can be used as a cover to provide a barrier to rainfall and also increase temperature. Sludge is more easily removed from a drying bed when the solids content reaches $30 \%$. Pathogens are removed in a drying bed by a combination of desiccation and UV disinfection. Drying obviously occurs better in dry and warm climates and much less in wet and cold climates.

Planted beds can improve dewatering through transpiration provided by deep rooted plants that also help with vertical drainage by roots. Reed bed technology use reeds (tall grasses that prefer marshy locations). The use of plants in dewatering sludge is described later in this chapter in the section that discusses desludging a wastewater lagoon.

\subsubsection{Solar drying}

Solar drying systems consist of a drying bed that in higher rainfall areas can be enclosed in drying chamber (similar to a greenhouse). Sludge can be turned and aerated by manual labor (using proper protective 
equipment) or mechanical methods. The enclosed systems may have a mechanical ventilation system installed. Moisture is evaporated from the system to achieve a final solids concentration of $70-90 \%$.

Short wavelength UV light has been found to be effective in reducing pathogen concentrations (Sinton et al., 2002); however, short wavelength UV light is blocked by the sludge layer and many commercial greenhouse roofs found in enclosed solar dryers. Therefore, pathogen die-off mechanisms in an enclosed solar dryer are most likely a result of a reduction in moisture content and exposure to higher temperatures. In one study of a full scale system (Australia), temperatures and moisture content were measured within the sludge along different locations in the solar dryer. Those results showed that the moisture content was reduced from $80 \%$ to $30-58 \%$ and a temperature of $67.5^{\circ} \mathrm{C}$ was recorded within the sludge. The authors also reported that though fecal coliforms were identified in the treated sludge, enteroviruses, parasites, E. coli, and Salmonella sp. were not detected in the solar dried product (Shanahan et al., 2010).

\subsubsection{Desludging a waste stabilization pond}

Removal of accumulating sludge from a waste stabilization pond is important to maintain proper hydraulic conditions which impacts pathogen removal (Ouedraogo et al., 2016). A general rule of thumb is to remove sludge from anaerobic ponds every 2-5 years and from a facultative pond every 5-15 years. Unfortunately, waste stabilization ponds are often designed and operated without consideration of desludging. Regarding design, for locations that use dry desludging methods (discussed below), ponds be designed with a slope towards the discharge side to promote water draining away from sludge that accumulates on the intake side. Furthermore, ponds are typically operated without the cost of desludging included in the operation and maintenance budget (Oakley et al., 2012).
Ponds can be desludged by wet or dry removal methods. Wet removal requires the use of sludge pumps, vacuum trucks, and dewatering equipment (Carré et al., 1990; Picot et al., 2005). Dry removal methods are less expensive and one method has been demonstrated in detail by Oakley et al. (2012). Greater details on sludge removal from waste stabilization ponds is available in Carré et al. (1990), Goncalves (1999), Picot et al. (2005), Von Sperling (2007), and Oakley et al. (2012).

Dry removal methods require that the sludge first be dried to a dry solid (18-20\% solids). Sludge changes from a liquid to a solid around this percent solids and after it becomes a solid it won't decrease in volume much more. The reason to dry the sludge first is is because heavy equipment will become stuck in deep sludge that is not dried to a solid. If the influent is routed away from a pond and the contents are allowed to drain so the sludge dries, deeper sludge will not dry because a crust will form on the surface that may extend to depth of 0.15 to $2 \mathrm{~m}$. This crust will prevent the deeper sludge from drying.

Oakley et al. (2012) presents a detailed method to desludge a waste stabilization pond, using a case study from Honduras. In this system, the pond is first drained to initiate the drying process. The detailed method provides a method to estimate the drying time from readily available information. It also provides equations to estimate the volume of sludge that will need to be removed. Wetland plants (preferably native) that have deep roots are then planted before the crust forms. The wetland plants are also selected so they grow quickly. The plants help to dewater the sludge to their root depth through evapotranspiration. This depth can extend to $>1$ $\mathrm{m}$. After drying of surface and deep sludge, the sludge can be removed with a mechanical excavator as shown in Figure 6.

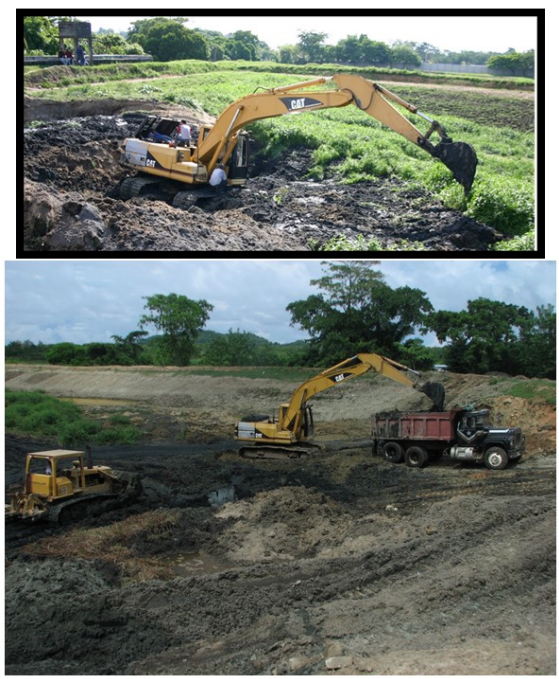

Figure 6. Waste stabilization pond sludge removal from waste stabilization pond in Tela, Honduras. In the upper photo an excavator removes surface and deep sludge (up to $1 \mathrm{~m}$ ) from pond planted with deep root wetland plants. In total, $3,000 \mathrm{~m}^{3}$ of dried sludge was removed in 5 days with the excavator (after pond was dried by draining and planting of deep rooted wetland plants) (photos provided by Stewart Oakley with permission). 
Dewatered sludge will contain pathogens, including helminths. Care thus needs to be made to ensure humans and livestock do not come in contact with the dewatered sludge. Pond designs should thus include reserving an area where excavated sludge can be safely stored for $\geq 1$ year to meet the WHO guidelines for inactivation of helminth eggs (WHO, 2006).

\subsection{Other Treatment Methods}

Fecal sludge has been treated using black solider flies (Hermetia illucens). A comprehensive manual on use of black soldier flies to process organic waste is available (Dortmans et al., 2017).

Black soldier fly larvae have been shown to grow on organic wastes such as fecal sludge. The larvae aerate the mixture and the resulting compost can be used as a soil conditioner. Some have suggested that the fly prepupae that are produced during composting could also be used to produce animal or aquaculture feed (Gabler, 2014) because the prepupae consist of $40 \%$ protein and $30 \%$ fat (Sheppard et al., 2002). This technology has been reported in laboratory experiments to reduce Salmonella spp. by $6 \log _{10}$ in eight days. No reduction was observed however over that same time period for Enterococcus spp., bacteriophage ФX174 or Ascaris suum ova (Lalander et al., 2013).

\subsection{Additional Information on Fecal Sludge Management}

As mentioned in the chapter's Introduction, fecal sludge is a distinct type of wastewater sludge that is generated onsite (e.g., discharge to toilet/latrine pits and septic tanks) and is not transported through a sanitary sewer. Many documents report specifically on fecal sludge management (e.g., Strande et al., 2014; Semiyaga et al., 2015; World Bank, 2017). Fecal sludge has different physical-chemical characteristics than sludge generated at a centralized treatment plant. These particular characteristics have been summarized elsewhere (Strande et al., 2014). Fecal sludge that has aged in a pit or tank is believed to have reduced pathogen levels in because of aerobic and anaerobic biological processes that occur in the pit. Furthermore, helminth egg concentrations are reported to be much higher in sludge collected from toilet/latrine pits and septic tank waste and raw sewage sludge (Semiyaga et al., 2015).

The service chain for fecal sludge management is provided in Figure 7. As shown in Figure 7, there is a potential for increased human health risk associated with exposure to pathogens present in the fecal sludge during the collection of the material and subsequent transport to a treatment or disposal facility. Thus design and management of toilet/latrine and septic systems in rural and urban areas must also consider safe collection and transport of the contents. This differs from a system where excreta is collected at the point of production and transported in a secure sanitary sewer to a centralized wastewater treatment plant. Sanitary sewers however are not perfect because they are known to develop cracks and can leak their contents to groundwater and surface water. They also come with added economic and environmental costs. For example, an economic comparison of a sanitary sewer connected to an activated sludge treatment system (a relatively more expensive sanitation technology) was compared to septic tank systems that were integrated with collection and transport of fecal sludge that was then treated in drying beds. That study (Dodane et al., 2012) showed the combined capital and operating costs for the centralized activated sludge system were five times greater than the decentralized onsite system with fecal sludge management. Bathroom and collection infrastructure have also been shown to have higher energy intensity (and thus carbon footprint) than associated treatment technologies such as waste stabilization ponds and upflow anaerobic sludge blanket reactors (Cornejo et al., 2013). 


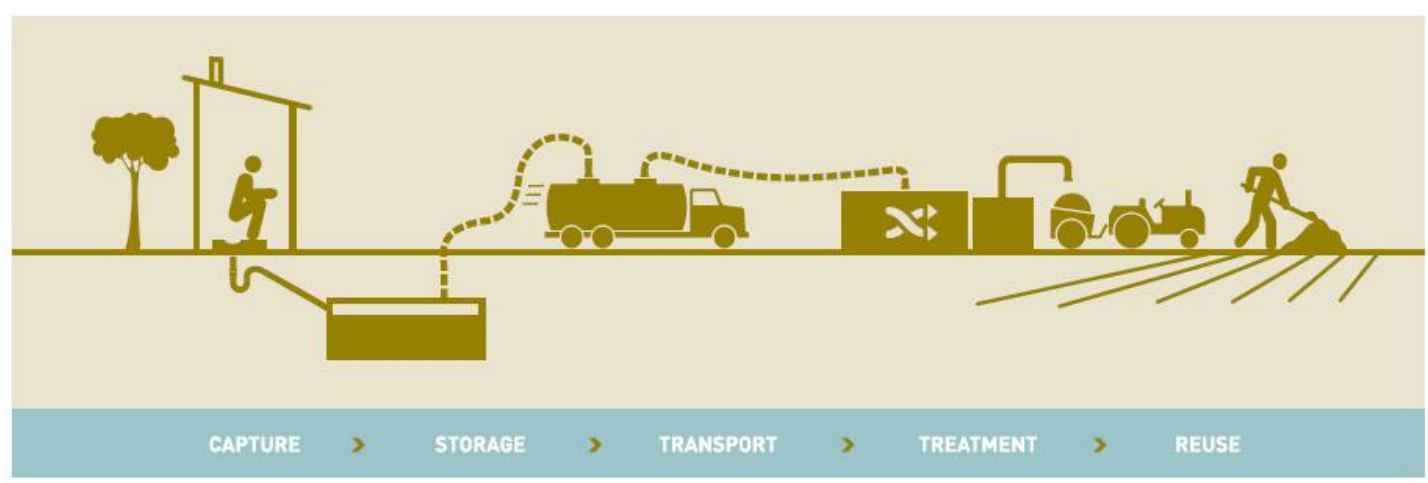

Figure 7. Fecal sludge sanitation service chain (reprinted from Water, Sanitation \& Hygiene Strategy Overview, Bill \& Melinda Gates Foundation, 2012)

In addition, fecal sludge is widely produced around the world, but is currently poorly managed. For example, in a study of twelve cities, approximately $66 \%$ of urban households were found to rely on onsite sanitation technology (WSP, 2014). These onsite systems would thus generate fecal sludge. However, only $22 \%$ of the fecal sludge produced in these 12 cities was estimated to be safely managed. One reason for this is because as currently practiced, fecal sludge management is mostly unplanned and managed by nonregulated informal private entities (WSP, 2014). To demonstrate the importance of the health implications of improper fecal sludge management, Figure 8 shows that for the example of Dakar, most human excreta is contained at the house level. However, as the fecal matter moves through the sanitation service chain, there is a large loss of it (and pathogens associated with the waste) to the urban environment. This example is not to say that decision makers should advocate only for centralized systems. This is because onsite wastewater management will have a continued role to play in rural and urban settings and sludge produced at a centralized treatment plant can also be unsafely managed.

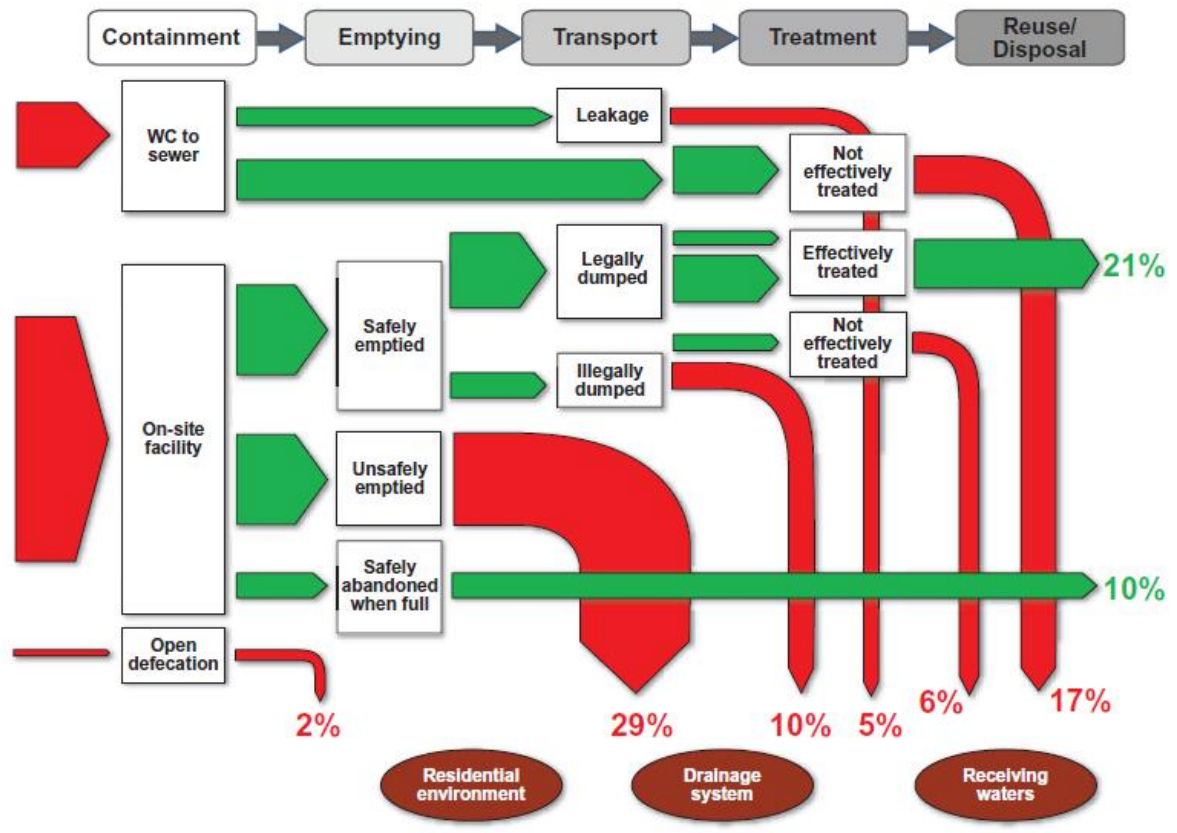

Figure 8. Fecal Waste Flow Diagram for Dakar (Senegal) (reproduced with permission from a Research Brief developed by the Water and Sanitation Program, The World Bank Group, 2014). 
After it is collected and transported, the fundamental processes of pathogen fate and the treatment technologies applied to fecal sludge are similar to processes and technologies described in Sections 3 and 4 of this chapter. Figure 9 shows how collection and treatment of fecal sludge is currently practiced in some parts of the world. Strande et al. (2014) provide design of many examples for technologies to treat fecal sludge.

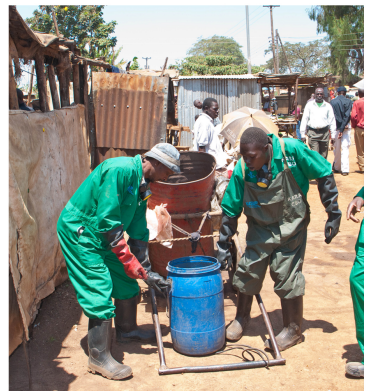

(a)

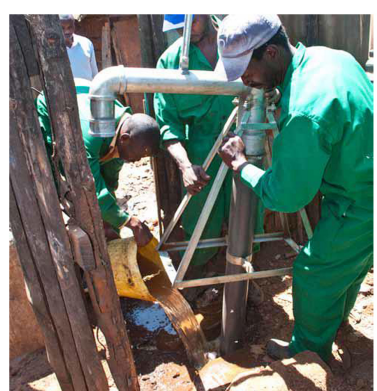

(b)

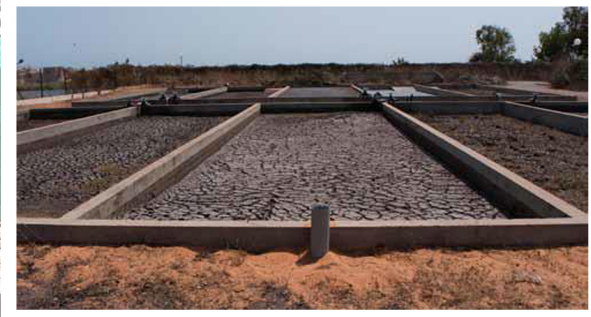

(c)

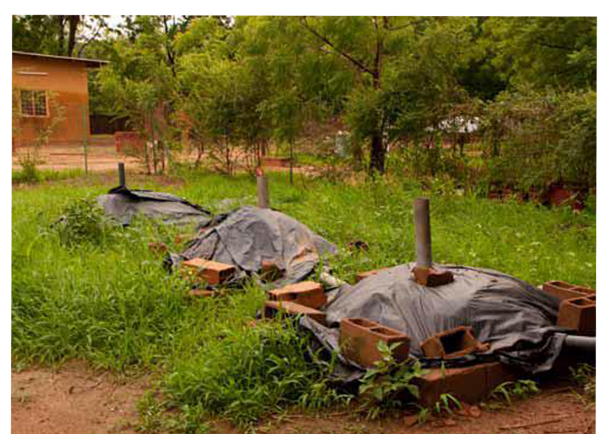

(d)

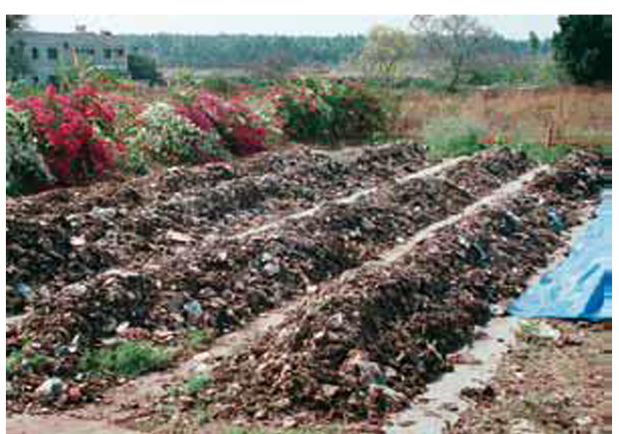

(e)

Figure 9. a) Transport of fecal sludge from an informal settlement in Nairobi. b) Addition of water to pit latrine to aid removal of pit contents in Nairobi, c) drying bed for treatment of fecal sludge in Dakar, d) biogas reactors used to stabilize fecal sludge in Ouagadougou, (photos (a-d) provided by Linda Strande with permission) pilot composting facility that combines fecal sludge and municipal solid waste in Bangalore (photo (e) provided by Christian Zurbrügg with permission).

\subsection{Data on Pathogen Reduction in Sludge Management Systems}

The removal of pathogens during sludge management clearly depends on a number of environmental factors as well as engineering design and operation and maintenance practices, as demonstrated in the previous sections. Data from a review of the literature have been collected about pathogen removal during sludge management. The following four factors were found to have the largest impact on pathogen removal: 1) retention time, 2) temperature, 3) $\mathrm{pH}$, and 4) moisture content. Sunlight exposure is not expected to result in significant removal of pathogens. These four factors are summarized in Table 9 . Table 10 provides a summary of typical pathogen removal efficiencies for specific technologies used for sludge management. 
Table 9. Summary of key factors and strategies to enhance pathogen removal in sludge management

\begin{tabular}{|c|c|c|c|c|c|}
\hline \multirow[t]{2}{*}{ Factor } & \multirow{2}{*}{$\begin{array}{c}\text { Pathogen Removal is } \uparrow \text { Enhanced or } \downarrow \text { Reduced Under the } \\
\text { Following Conditions }\end{array}$} & \multicolumn{4}{|c|}{ Pathogen Group } \\
\hline & & Viruses & Bacteria & Protists & Helminths \\
\hline $\begin{array}{l}\text { Sludge } \\
\text { Temperature }\end{array}$ & Higher Temperature $=\uparrow$ Pathogen Removal & $\mathrm{X}^{\mathrm{a}}$ & $\mathrm{X}$ & $\mathrm{X}$ & $\mathrm{X}$ \\
\hline $\begin{array}{l}\text { Retention } \\
\text { Time }\end{array}$ & Longer Retention Time $=\uparrow$ Pathogen Removal & $\mathrm{XX}$ & $\mathrm{XX}$ & $\mathrm{XX}$ & $\mathrm{XX}$ \\
\hline $\mathrm{pH}$ & Higher $\mathrm{pH}=\uparrow$ Pathogen Removal & $\mathrm{XX}$ & $\mathrm{XX}$ & $\mathrm{X}$ & $\mathrm{X}$ \\
\hline $\begin{array}{l}\text { Free } \\
\text { ammonia } \\
\text { concentration }\end{array}$ & Higher NH3 concentration $=\uparrow$ Pathogen Removal & $\mathrm{XX}$ & $\mathrm{XX}$ & $\mathrm{XX}$ & $\mathrm{XX}$ \\
\hline $\begin{array}{l}\text { Moisture } \\
\text { Content }\end{array}$ & Lower Moisture $=\uparrow$ Pathogen Removal & $\mathrm{XX}$ & $\mathrm{XX}$ & $\mathrm{XX}$ & $\mathrm{XX}$ \\
\hline $\begin{array}{l}\text { Sunlight (UV) } \\
\text { Exposure }\end{array}$ & $\begin{array}{l}\text { Sunlight (UV) exposure is not expected to be a significant removal } \\
\text { mechanism for most technologies used for sludge management } \\
\text { unless it raises temperature or results in desiccation of the sludge }\end{array}$ & & & & \\
\hline
\end{tabular}

Table 10. Summary of indicator and pathogen removal for specific sludge management technologies

\begin{tabular}{|c|c|c|c|c|}
\hline $\begin{array}{c}\text { Sludge } \\
\text { Management } \\
\text { Technology }\end{array}$ & $\begin{array}{c}\text { Expected } \\
\text { Indicator } \\
\text { and } \\
\text { Pathogen } \\
\text { Destruction }\end{array}$ & Organisms & $\begin{array}{c}\log _{10} \\
\text { Reduction }\end{array}$ & Reference \\
\hline $\begin{array}{l}\text { Aerobic } \\
\text { Digestion }\end{array}$ & $\begin{array}{l}\text { Thermophilic } \\
\text { digestion is } \\
\text { more efficient } \\
\text { at removing } \\
\text { pathogens } \\
\text { than } \\
\text { mesophilic } \\
\text { digestion } \\
\text { Helminth ova } \\
\text { are reduced } \\
\text { to varying } \\
\text { degrees, } \\
\text { depending on } \\
\text { the hardiness } \\
\text { of the } \\
\text { individual } \\
\text { species }\end{array}$ & $\begin{array}{c}\text { Fecal indicators, bacterial } \\
\text { organisms and viral } \\
\text { pathogens }\end{array}$ & 1 & $\begin{array}{l}\text { USEPA, } \\
2003\end{array}$ \\
\hline
\end{tabular}




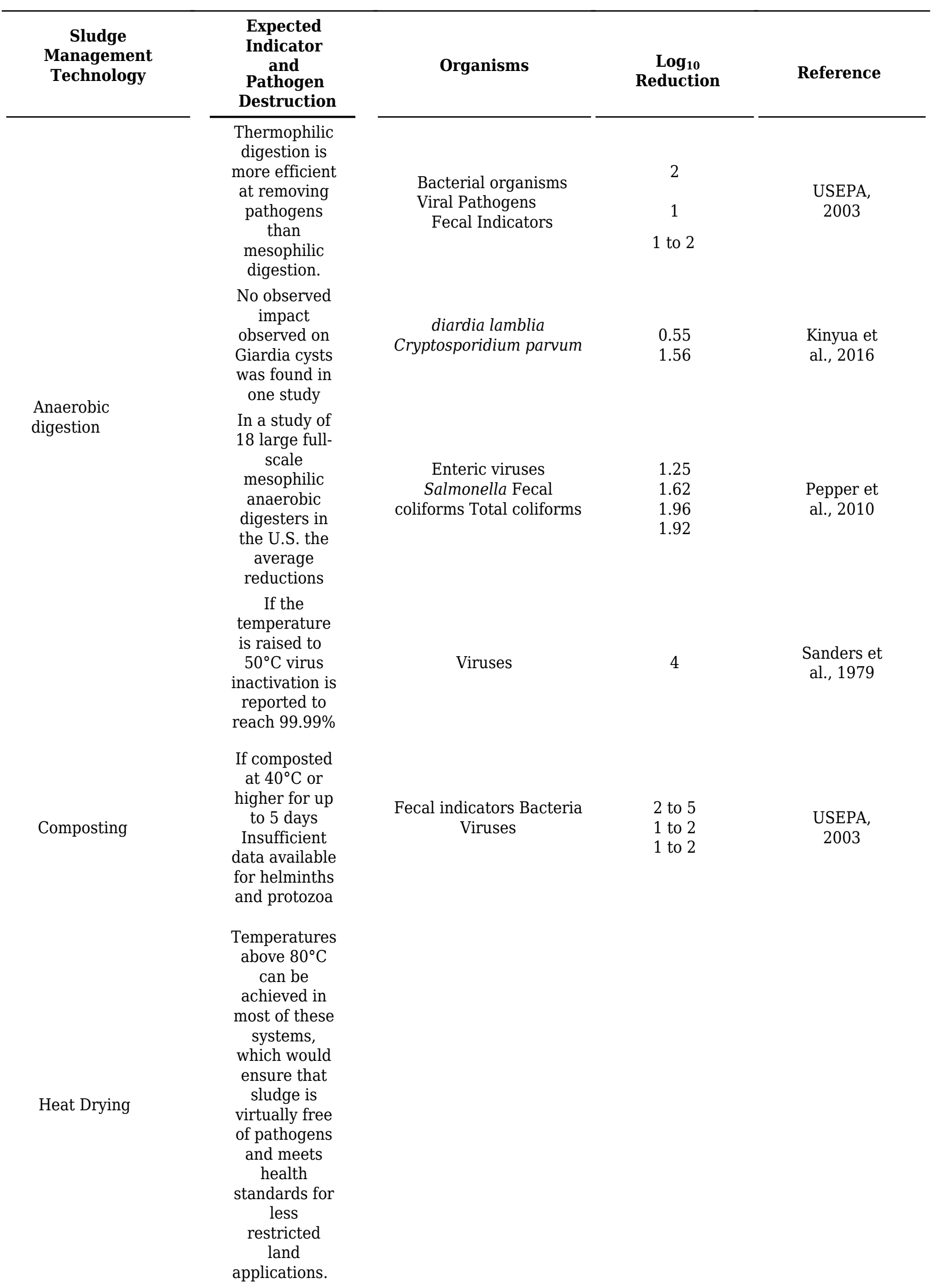




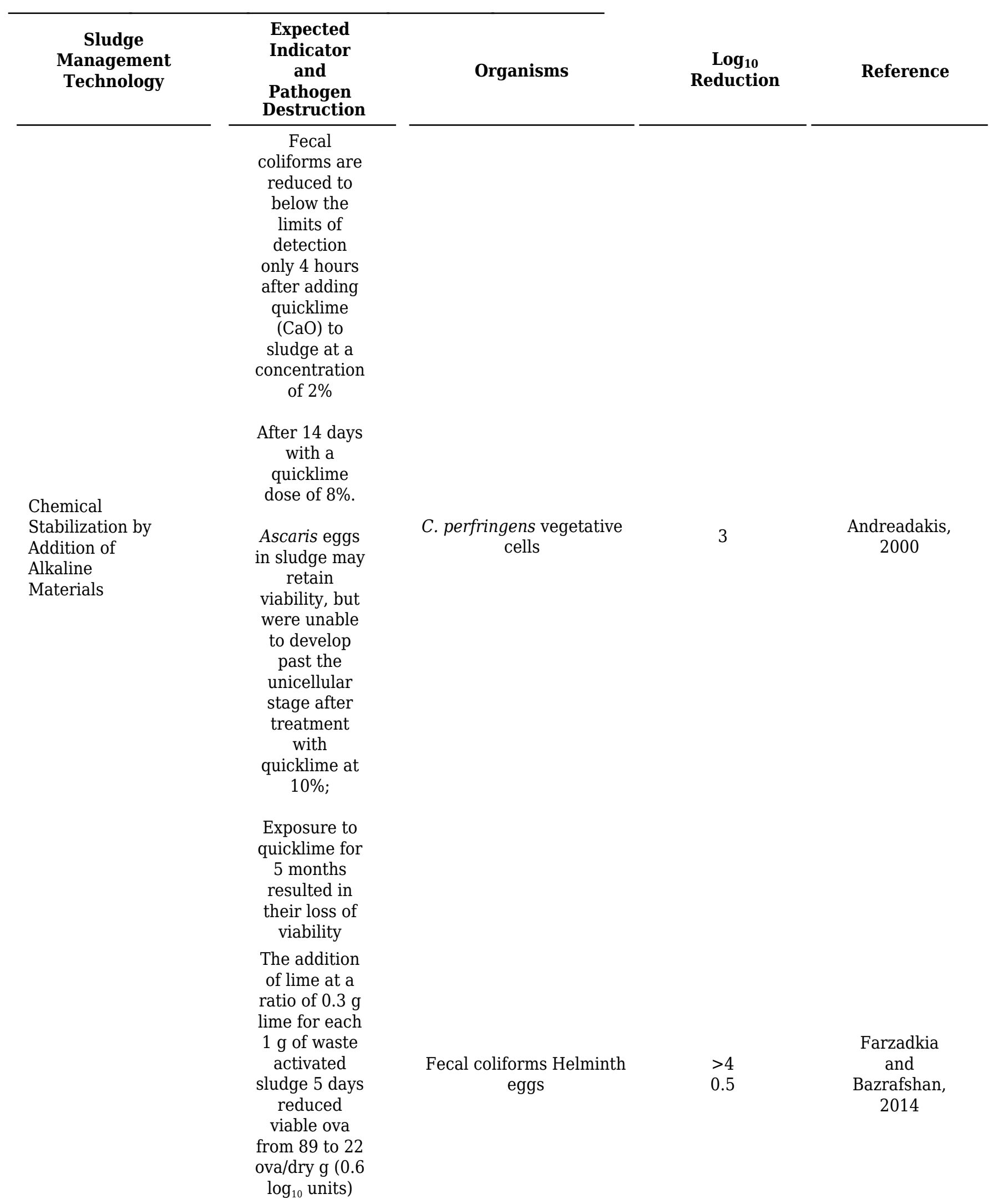




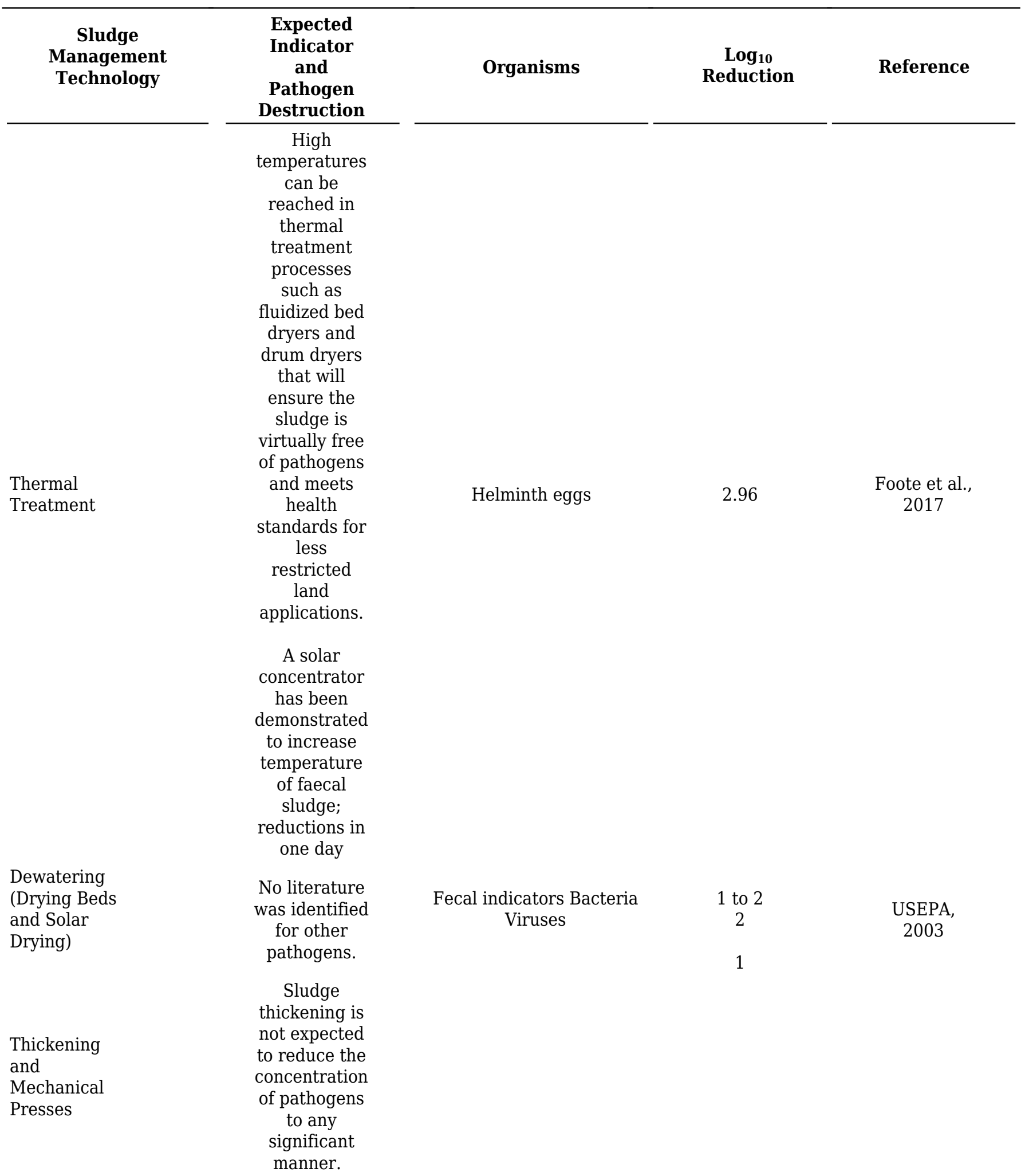

\subsection{Conclusions}

During sludge processing, pathogens are inactivated by different mechanisms. The efficiency of these mechanisms is dependent on a number of environmental, design, and operational factors. Temperature and time have been identified as perhaps the two most important factors in achieving significant pathogen destruction during sludge management (Sahlström, 2003) and pH and moisture content are also important. Examples of sludge management technologies that can achieve temperatures greater than $45^{\circ} \mathrm{C}$ if properly designed and operated are: 1) composting, 2) thermal treatment, and 3) thermophilic digestion. For lower temperature treatments, pathogen concentrations are reduced but still routinely identified in treated sludge (Gantzer et al., 2001).

Other ways to improve pathogen destruction during sludge treatment are reducing moisture content by drying (through evaporation, transpiration by use of deep rooted 
plants, and drainage of water vertically from a drying bed), raising $\mathrm{pH}$, and/or increasing the concentration of free (unionized) ammonia. Sunlight's role in decreasing pathogen concentrations in sludge is mostly through supporting desiccation of drying sludge (USEPA, 2003). Biological processes (e.g., digestion, composting) can reduce the volatile organic fraction of sludge; thus, reducing disease vector attraction and bacterial growth because of loss of available organic substrate (USEPA, 2003).
Table 11 provides recommendations made by the World Health Organization (2006) for storage treatment of dried excreta and fecal sludge. Note the information provided in this table shows the importance of storage time, temperature, and $\mathrm{pH}$ in reducing pathogen levels. The World Health Organization also recommends an additional barrier of safety of waiting one month between the time the stored excreta is applied to a crop and the time the crop is harvested.

Table 11. World Health Organization (WHO) recommendations for storage treatment of dry excreta and fecal sludge (reprinted with permission from Table 2 (Page xvi) from the WHO 2006 Guidelines for the Safe Use of Wastewater, Excreta, and Greywater Volume 4 Excreta and Greywater Use in Agriculture, 2006.)

\begin{tabular}{|c|c|c|}
\hline Treatment & Criteria & Comment \\
\hline $\begin{array}{l}\text { Storage at } \\
\text { ambient } \\
\text { temperature } \\
\text { of } 2 \text { to } 20^{\circ} \mathrm{C}\end{array}$ & $\begin{array}{l}6 \text { months } \\
\text { to } 2 \text { years }\end{array}$ & $\begin{array}{l}\text { Eliminates bacterial pathogens, regrowth of E. coli and Salmonella may need to be } \\
\text { considered if rewetted; will reduce viruses and parasitic protozoa below risk levels. Some } \\
\text { soil-borne ova may persist in low numbers. }\end{array}$ \\
\hline $\begin{array}{l}\text { Storage at } \\
\text { temperature } \\
>20 \text { to } \\
35^{\circ} \mathrm{C}\end{array}$ & $>1$ year & $\begin{array}{c}\text { Substantial to total inactivation of viruses, bacteria, and protozoa; inactivation of schistosome } \\
\text { eggs ( }<1 \text { month); inactivation of nematode (roundworm) eggs; survival of a certain } \\
\text { percentage (10 to 30\%) of Ascaris eggs ( } \geq 4 \text { months), where a more or less complete } \\
\text { inactivation of Ascaris eggs will occur within } 1 \text { year. }\end{array}$ \\
\hline $\begin{array}{l}\text { Alkaline } \\
\text { Treatment }\end{array}$ & $\begin{array}{l}\mathrm{pH}>9 \\
\text { for }>6 \\
\text { months }\end{array}$ & $\begin{array}{c}\text { If temperatures }>35^{\circ} \mathrm{C} \text { and moisture is }<25^{\circ} \mathrm{C} \text {, lower } \mathrm{pH} \text { and/or wetter material will prolong } \\
\text { the time for absolute elimination }\end{array}$ \\
\hline
\end{tabular}

Helminth eggs are particularly resistant to sludge treatment processes, including thermal and chemical treatment. Therefore, in regions where helminths are endemic, it is recommended that sludge be reused with extreme caution, especially given that few laboratories in these regions are equipped to monitor helminths in sludge on a routine basis. In regions where helminth infections regularly occur, it is recommended to manage sludge in these settings to provide simple treatment in sludge-drying beds, and then to bury the dried sludge to further reduce health risks by minimizing exposure (Figure 10).

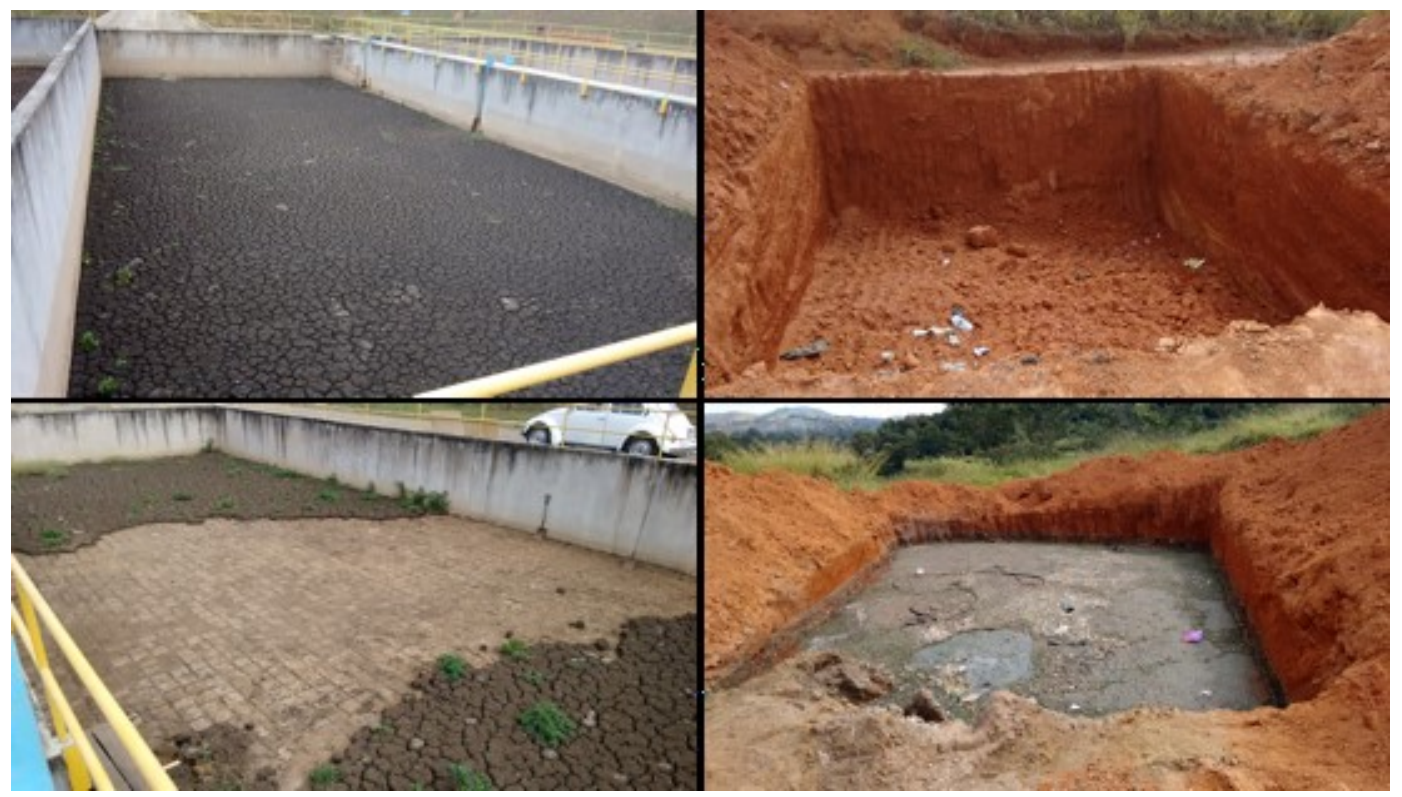

Figure 10. Example of safe management of sludge in a small town in southern Brazil with sludge drying beds (upper left), emptied manually by personnel using protective equipment (lower left); dried sludge is then buried onsite in pits (upper and lower right) (photos provided by Matthew E. Verbyla with permission) 


\section{References}

Aitken, M.D., Sobsey, M.D., Blauth, K.E., Shehee, M., Crunk, P.L. and Walters, G.W. (2005). Inactivation of Ascaris suum and poliovirus in biosolids under thermophilic anaerobic digestion conditions. Environmental Science and Technology. 39, pp. 5804-5809.

Andreadakis, A.D. (1999). Treatment and disinfection of sludge using quicklime. DGE/JRCEC European Commission Workshop Around Sludge, Italy, Stresa. pp. 18-19.

Andreoli, C.V., von Sperling, M., Fernandes, F. and Ronteltap, M. (2007). Sludge treatment and disposal. IWA Publishing. London, United Kingdom.

Arthurson, V. (2008). Proper sanitization of sewage sludge: a critical issue for a sustainable society. Applied and Environmental Microbiology. 74, pp. 5267-5275.

Bruun, S., Jensen, L.S. and Sommer, S. (2014). Small-scale household biogas digesters: An option for global warming mitigation or a potential climate bomb?. Renewable and Sustainable Energy Reviews. 33, pp. 736-741.

Burton, F.L., Stensel, H.D. and Tchobanoglous, G. (2014). Wastewater engineering: treatment and resource recovery. 5th ed. McGraw-Hill.

Butkus, M.A., Hughes, K.T., Bowman, D.D., Liotta, J.L., Jenkins, M.B. and Labare, M.P. (2011). Inactivation of Ascaris suum by short-chain fatty acids. Applied and Environmental Microbiology. 77, pp. 363-366.

Carre, J., Laigre, M.P. and Legeas, M. (1990). Sludge removal from some wastewater stabilization ponds. Water Science and Technology. 22, pp. 247-252.

Chauret, C., Springthorpe, S. and Sattar, S. (1999). Fate of Cryptosporidium oocysts, Giardia cysts, and microbial indicators during wastewater treatment and anaerobic sludge digestion. Canadian Journal of Microbiology. 45(3), pp. 257-262.

Cornejo, P.K., Zhang, Q. and Mihelcic, J.R. (2013). Quantifying benefits of resource recovery from sanitation provision in a developing world setting. Journal of Environmental Management. 131, pp. 7-15.

Darimani, H.S., Ito, R., Sou, M., Dakoure, N.F., Yacouba, H. and Maiga, A.H. (2015). Design of Post-Treatment Unit for Compost from a Composting Toilet with Microbial Risk Assessment. Journal of Residuals Science and Technology.

Diener, S., Semiyaga, S., Niwagaba, C.B., Muspratt, A.M., Gning, J.B., Mbéguéré, M. et al. (2014). A value proposition: Resource recovery from faecal sludge-Can it be the driver for improved sanitation?. Resources, Conservation and Recycling. 88, pp. 32-38.

Dodane, P.H., Mbéguéré, M., Sow, O. and Strande, L. (2012). Capital and operating costs of full-scale fecal sludge management and wastewater treatment systems in Dakar, Senegal. Environmental Science and Technology. 46, pp. 3705-3711. 
Dortmans, B.M., Diener, S., Verstappen, B. and Zurbrügg, C. (2017). Black Soldier Fly Biowaste Processing-A Step-by-Step Guide [online]. Dübendorf, Switzerland: Eawag-Swiss Federal Institute of Aquatic Science and Technology.

Drechsel, P., Scott, C., Raschid-Sally, L., Redwood, M. and Bahri, A. (2010). Wastewater Irrigation and Health: assessing and mitigating risk in low-income countries. Earthscan.

Dumontet, S., Dinel, H. and Baloda, S.B. (1999). Pathogen reduction in sewage sludge by composting and other biological treatments: A review. Biological Agriculture and Horticulture. 16, Taylor and Francis. pp. 409-430.

Eastman, B.R., Kane, P.N., Edwards, C.A., Trytek, L., Gunadi, B., Stermer, A.L. et al. (2001). The effectiveness of vermiculture in human pathogen reduction for USEPA biosolids stabilization. Compost Science and Utilization. 9, pp. 38-49.

Espinoza, L.M.C., Yeh, D., Vinneras, B., Rajaram, L., Whiteford, L., Corvin, J. et al. (2012). Inactivation of Ascaris suum by ammonia in feces simulating the parameters of the solar toilet. Journal of Applied Sciences in Environmental Sanitation.

Farrell, J.B., Erlap, A.E., Rickabaugh, J., Freedman, D. and Hayes, S. (1988). Influence of feeding procedure on microbial reductions and performance of anaerobic digestion. Journal (Water Pollution Control Federation). JSTOR. pp. 635-644.

Farzadkia, M. and Bazrafshan, E. (2014). Lime stabilization of waste activated sludge. Health Scope. 3, Kowsar.

Feachem, R.G., Bradley, D.J., Garelick, H. and Mara, D.D. (1981). Appropriate Technology for Water Supply and Sanitation: Health Aspects of Excreta and Sullage Management- A State-of-the-Art Review. World Bank.

Feachem, R.G., Mara, D.D. and Bradley, D.J. (1983). Sanitation and disease. John Wiley and Sons Washington DC, USA.

Fernandes, F. (2000). Estabilização e higienização de biossólidos. Impacto Ambiental do uso agrícola do lodo de esgosto. Jaguariúna: EMBRAPA. pp. 45-67.

Foote, A.M., Woods, E., Fredes, F. and Leon, J.S. (2017). Rendering fecal waste safe for reuse via a cost-effective solar concentrator. Journal of Water Sanitation and Hygiene for Development. 7, pp. 252-259.

Franceys, R., Pickford, J. and Reed, R. (1992). A guide to the development of on-site sanitation. World Health Organization. Geneva, Switzerland.

Gabler, F. and Vinnerås, B. (2014). Using Black Soldier Fly for waste recycling and effective Salmonella spp. reduction. Energy and Technology. Swedish University of Agricultural Sciences.

Gantzer, C., Gaspard, P., Galvez, L., Huyard, A., Dumouthier, N. and Schwartzbrod, J. (2001). Monitoring of bacterial and parasitological contamination during various treatment of sludge. Water Research. 35, pp. 3763-3770.

Gaspard, P.G., Wiart, J. and Schwartzbrod, J. (1995). Urban sludge reuse in agriculture: waste treatment and parasitological risk. Bioresource Technology. 52(1), pp. 37-40. 
Goncalves, R.F. (1999). Gerenciamento do lodos de lagoas de estabilizaçâo nâo mecanizadas. Gerenciamento do lodos de lagoas de estabilizaçâo nâo mecanizadas. PROSAB.

Horan, N.J., Fletcher, L., Betmal, S.M., Wilks, S.A. and Keevil, C.W. (2004). Die-off of enteric bacterial pathogens during mesophilic anaerobic digestion. Water Research. 38, pp. 1113-1120.

Humphrey, N. (1999). E. Coli in UK Mesophilic Anaerobically Digested Sludges. UK Water Industry Research Limited.

Imhoff, K. and Hess, M.L. (1966). Manual de tratamento de águas residuais. Edgard Blucher.

Jiménez, B. (2007). Helminth ova control in sludge: A review. Water Science and Technology. 56, pp. 147-155.

Kabrick, R.M. and Jewell, W.J. (1982). Fate of pathogens in thermophilic aerobic sludge digestion. Water Research. 16, pp. 1051-1060.

Kinyua, M.N., Trimmer, J., Izurieta, R., Cunningham, J. and Ergas, S.J. (2016). Viability and fate of Cryptosporidium parvum and Giardia lamblia in tubular anaerobic digesters. Science of the Total Environment. 554, pp. 167-177.

Kunte, D.P., Yeole, T.Y., Chiplonkar, S.A. and Ranade, D.R. (1998). Inactivation of Salmonella typhi by high levels of volatile fatty acids during anaerobic digestion. Journal of Applied Microbiology. 84, pp. 138-142.

Kunte, D.P., Yeole, T.Y. and Ranade, D.R. (2000). Effect of volatile fatty acids on Shigella dysenteriae during anaerobic digestion of human night soil. World Journal of Microbiology and Biotechnology. 16, pp. 519-522.

Lalander, C., Diener, S., Magri, M.E., Zurbrügg, C., Lindström, A. and Vinnerås, B. (2013). Faecal sludge management with the larvae of the black soldier fly (Hermetia illucens)-From a hygiene aspect. Science of the Total Environment. 458, pp. 312-318.

Malina, J.F. (1993). Effectiveness of municipal sludge treatment processes in eliminating indicator organisms. Joint Residuals Conference.

Manser, N.D., Cunningham, J.A., Ergas, S.J. and Mihelcic, J.R. (2016). Modeling inactivation of highly persistent pathogens in household-scale semi-continuous anaerobic digesters. Environmental Engineering Science. 33, pp. 851-860.

Manser, N.D., Wald, I., Ergas, S.J., Izurieta, R. and Mihelcic, J.R. (2015). Assessing the fate of Ascaris suum ova during mesophilic anaerobic digestion. Environmental Science and Technology. 49, pp. 3128-3135.

Mehl, J., Kaiser, J., Hurtado, D., Gibson, D.A., Izurieta, R. and Mihelcic, J.R. (2011). Pathogen destruction and solids decomposition in composting latrines: study of fundamental mechanisms and user operation in rural Panama. Journal of Water and Health. 9, pp. 187-199.

Mihelcic, J.R., Myre, E.A., Fry, L.M., Phillips, L.D. and Barkdoll, B.D. (2009). Field Guide in Environmental Engineering for Development Workers: Water, Sanitation, Indoor Air. 
Mihelcic, J.R. and Zimmerman, J.B. (2014). Environmental engineering: Fundamentals, sustainability, design. Wiley Global Education.

Mocé-Llivina, L., Muniesa, M., Pimenta-Vale, H., Lucena, F. and Jofre, J. (2003). Survival of bacterial indicator species and bacteriophages after thermal treatment of sludge and sewage. Applied and Environmental Microbiology. 69, pp. 1452-1456.

Monpoeho, S., Maul, A., Bonnin, C., Patria, L., Ranarijaona, S., Billaudel, S. et al. (2004). Clearance of human-pathogenic viruses from sludge: study of four stabilization processes by real-time reverse transcription-PCR and cell culture. Applied and Environmental Microbiology. 70, pp. 5434-5440.

Monteleone, M.C., Furness, D., Jefferson, B. and Cartmell, E. (2004). Fate of E. coli across mechanical dewatering processes. Environmental Technology. 25, pp. 825-831.

National Research Council (2002). Biosolids applied to land: advancing standards and practices. National Academies Press.

Nordin, A., Nyberg, K. and Vinnerås, B. (2009). Inactivation of Ascaris eggs in source-separated urine and feces by ammonia at ambient temperatures. Applied and Environmental Microbiology. 75, pp. 662-667.

Oakley, S.M., Mendonça, L.C. and Mendonça, S.R. (2012). Sludge removal from primary wastewater stabilization ponds with excessive accumulation: a sustainable method for developing regions. Journal of Water Sanitation and Hygiene for Development. 2, pp. 68-78.

Oakley, S. and Salguero, L. (2011). Tratamiento de aguas residuales domésticas en Centroamérica. Agencia de los Estados Unidos para el Desarrollo Internacional. San Salvador, El Salvador.

Ouedraogo, F.R., Zhang, J., Cornejo, P.K., Zhang, Q., Mihelcic, J.R. and Tejada-Martinez, A.E. (2016). Impact of sludge layer geometry on the hydraulic performance of a waste stabilization pond. Water Research. 99, pp. 253-262.

Pecson, B.M., Barrios, J.A., Jimenez, B.E. and Nelson, K.L. (2007). The effects of temperature, pH, and ammonia concentration on the inactivation of Ascaris eggs in sewage sludge. Water Research. 41, pp. 2893-902. doi: 10.1016/j.watres.2007.03.040.

Pepper, I.L., Brooks, J.P., Sinclair, R.G., Gurian, P.L. and Gerba, C.P. (2010). Pathogens and indicators in United States Class B biosolids: National and historic distributions. Journal of Environmental Quality. 39, pp. 2185-2190.

Picot, B., Sambuco, J.P., Brouillet, J.L. and Riviere, Y. (2005). Wastewater stabilisation ponds: sludge accumulation, technical and financial study on desludging and sludge disposal case studies in France. Water Science and Technology. 51, pp. 227-234.

Popat, S.C., Yates, M.V. and Deshusses, M.A. (2010). Kinetics of inactivation of indicator pathogens during thermophilic anaerobic digestion. Water Research. 44, pp. 5965-5972.

Reinoso, R., Becares, E. and Smith, H.V. (2008). Effect of various environmental factors on the viability of Cryptosporidium parvum oocysts. Journal of Applied Microbiology. 104, pp. 980-986. 
Sahlström, L. (2003). A review of survival of pathogenic bacteria in organic waste used in biogas plants. Bioresource Technology. 87, pp. 161-166.

Sanders, D.A., Malina, J.F., Moore, B.E., Sagik, B.P. and Sorber, C.A. (1979). Fate of poliovirus during anaerobic digestion. Journal Water Pollution Control Federation. 51(2), pp. 333-343.

Sanguinetti, G.S., Tortul, C., Garcia, M.C., Ferrer, V., Montangero, A. and Strauss, M. (2005). Investigating helminth eggs and Salmonella sp. in stabilization ponds treating septage. Water Science and Technology. 51, pp. 239-247.

Semiyaga, S., Okure, M.A.E., Niwagaba, C.B., Katukiza, A.Y. and Kansiime, F. (2015). Decentralized options for faecal sludge management in urban slum areas of Sub-Saharan Africa: A review of technologies, practices and end-uses. Resources, Conservation and Recycling. 104, pp. 109-119.

Sheppard, D.C., Tomberlin, J.K., Joyce, J.A., Kiser, B.C. and Sumner, S.M. (2002). Rearing methods for the black soldier fly (Diptera: Stratiomyidae). Journal of Medical Entomology. 39, pp. 695-698.

Sidhu, J.P.S. and Toze, S.G. (2009). Human pathogens and their indicators in biosolids: a literature review. Environment International. 35, pp. 187-201.

Sinton, L.W., Hall, C.H., Lynch, P.A. and Davies-Colley, R.J. (2002). Sunlight inactivation of fecal indicator bacteria and bacteriophages from waste stabilization pond effluent in fresh and saline waters. Applied and Environmental Microbiology. 68, pp. 1122-1131.

Soares, A.C., Straub, T.M., Pepper, I.L. and Gerba, C.P. (1994). Effect of anaerobic digestion on the occurrence of enteroviruses and Giardia cysts in sewage sludge. Journal of Environmental Science and Health Part A. 29, pp. 1887-1897.

Strande, L., Ronteltap, M. and Brdjanovic, D. (2014). Faecal Sludge Management (FSM) Book-Systems Approach for Implementation and Operation. London, United Kingdom: IWA Publishing.

Sykora, J.L., Sorber, C.A., Jakubowski, W., Casson, L.W., Gavaghan, P.D., Shapiro, M.A. et al. (1991). Distribution of Giardia cysts in wastewater. Water Science and Technology. 24, pp. 187-192.

Trimmer, J.T., Nakyanjo, N., Ssekubugu, R., Sklar, M., Mihelcic, J.R. and Ergas, S.J. (2016). Estimation of Ascaris lumbricoides egg inactivation by free ammonia treatment of ash-amended UDDT vault products using stored urine in Uganda. Journal of Water Sanitation and Hygiene for Development. 6, pp. 259-268.

USEPA (2003). Environmental Regulations and Technology Control of Pathogens and Vector Attraction in Sewage Sludge. USEPA Office of Research Development.

USEPA (1994). A plain english guide to the EPA part 503 biosolids rule. USEPA Office of Wastewater Management, Washington, DC. USEPA Office of Wastewater Management, Washington, DC.

Viau, E. and Peccia, J. (2009). Survey of wastewater indicators and human pathogen genomes in biosolids produced by class A and class B stabilization treatments. Applied and Environmental Microbiology. 75, pp. 164-174. 
Vinnerås, B. (2007). Comparison of composting, storage and urea treatment for sanitising of faecal matter and manure. Bioresource Technology. 98, pp. 3317-3321.

von Sperling, M. (2007). Waste stabilisation ponds. Biological Wastewater Treatment Series. 3, IWA publishing. London, United Kingdom.

Water Sanitation Program (2014). The missing link in sanitation service delivery: A review of fecal sludge management in 12 cities. World Bank.

Westrell, T., Schönning, C., Stenström, T.A. and Ashbolt, N.J. (2004). QMRA (quantitative microbial risk assessment) and HACCP (hazard analysis and critical control points) for management of pathogens in wastewater and sewage sludge treatment and reuse. Water Science and Technology. 50, pp. 23-30.

WHO (2006). Guidelines for the safe use of wastewater, excreta and greywater: Volume 4: Excreta and greywater use in agriculture. 3rd ed.4, World Health Organization. Geneva, Switzerland.

WHO (2006). Guidelines for the safe use of wastewater, excreta and greywater. Volumes I-IV. World Health Organization.

World Bank (2016). Fecal Sludge Management Tools. 